\begin{tabular}{|c|c|c|c|}
\hline \multirow{2}{*}{ 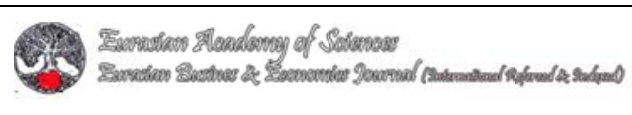 } & \multicolumn{3}{|c|}{$\begin{array}{l}\text { Eurasian Academy of Sciences } \\
\text { Eurasian Business \& Economics Journal }\end{array}$} \\
\hline & 2015 & Volume:1 & S: $94-120$ \\
\hline \multicolumn{4}{|c|}{$\begin{array}{c}\text { Published Online April } 2015 \text { (http://busecon.eurasianacademy.org) } \\
\text { http://dx.doi.org/10.17740/eas.econ.2015-V1-05 }\end{array}$} \\
\hline
\end{tabular}

\title{
BUDGET DEFICITS, THEIR ROLES IN THE ECONOMIC CRISES AND THE EFFECTIVENESS OF STABILIZATION PROGRAMS (IN CASE OF TURKEY AFTER 1990'S)
}

\author{
Cuma Çataloluk*, Halil Kete**
}

Gaziosmanpaşa Üniversitesi İİBF Maliye Bölümü*, Kırklareli Üniversitesi İ̇̈B Maliye Bölümü**

E-mail: cuma.cataloluk@gop.edu.tr*, halil.kete@klu.edu.tr**

Copyright (C) 2015 Cuma Çataloluk, Halil Kete. This is an open access article distributed under the Eurasian Academy of Sciences License, which permits unrestricted use, distribution, and reproduction in any medium, provided the original work is properly cited.

\begin{abstract}
Economic crises frequently experienced in Turkey cause increases in budget deficit and as these deficits cannot be closed they bring new crises. So, the "stabilization programs" that tried to be implemented during crises become quite important. In this study, the effectiveness of stabilization programs in closing budget deficit implemented during crises in Turkey, has been analyzed. Especially it has been investigated that why some stabilization programs failed while others succeeded in closing the budget deficits emerged by the beginning of 1990s and reached its peak in 2000s. Also crises in 1994, 2000 and 2001 which substantially damaged economic balance in the period after 1990 and lastly the impact of 2008 global crisis have been researched. Success of stabilization programs in closing budget deficit, which were implemented during these crises, stabilization measurements in 5th April, inflation reduction program in 2000, transition to strong economy program in 2001 and urgent action plan in 2002, were tried to understand through actual budget figures and economic data.
\end{abstract}

Keywords: Budget, Budget Deficit, Economic Crisis, Stabilization Programs, Budget Financing.

JEL-Clasification: H61 - H62 - H68 - H12 - G01

\section{Bütçe Açıları, Krizlerdeki Rolleri ve Krizleri Önlemeye Yönelik İstikrar Politikalarının Etkinliği (1990 Sonrası Türkiye Örneği) ${ }^{1}$}

ÖZET: Türkiye'de çok sık aralıklarla yaşanan ekonomik krizler, bütçe açıklarının büyümesine neden olmakta, kapatılamayan bütçe açıkları ise yeni krizlere yol açmaktadır. Kriz dönemlerinde uygulanan "istikrar paketleri" ise, bütçe açıklarının kapatılmasında oldukça büyük bir öneme sahiptir. Bu çalışmada, Türkiye'de bütçe açıkları, neden oldukları ekonomik krizler ve krizleri önlemeye yönelik istikrar paketlerinin etkinliği incelenmiştir.

\footnotetext{
${ }^{1}$ Türkiye'de Kriz Dönemlerinde Bütçe Açıklarının Kapatılmasında İstikrar Politikalarının Rolü , adlı yüksek lisans tezinden türetilmiştir.
} 
Özellikle 1990'lı y1llarda başlayan ve 2000'li y1llarda en üst seviyelere ulaşan bütçe açıklarının kapatılmasında, bazı istikrar paketleri başarısız olurken, bazılarının ise diğerlerine nazaran daha başarılı olduğunun sebepleri incelenmiştir. Aynı zamanda, 1990 sonrası dönemde, ekonomik dengeleri büyük oranda bozan 1994 Krizi, 2000 ve 2001 Krizleri ve son olarak da 2008 y1lında yaşanan küresel krizin etkileri incelenmiştir. Bu kriz dönemlerinde uygulamaya konulan, 5 Nisan İstikrar Tedbirleri, 2000 yılı Enflasyonu Düşürme Programı, 2001 yılı Güçlü Ekonomiye Geçiş Programı ve 2002 yılı Acil Eylem Planları olarak bilinen istikrar paketlerinin bütçe açıklarının kapatılmasında başarısı, gerçekleşen bütçe rakamları ve sağlanan ekonomik verilerle anlaşılmaya çalışılmıştır.

Anahtar Kelimeler: Bütçe, Bütçe Açıkları, Ekonomik Kriz, İstikrar Paketleri, Bütçe Finansman1.

\section{Giriş}

Bir ülkede temel makroekonomik ölçülerden biri bütçe açıklarıdır. Bütçe açıklarının birçok tanımı yapılmakla birlikte temel olarak; kamu harcamalarının kamu gelirlerini aşması sonucu ortaya çıkan farktır. Özellikle Keynesyen iktisadın açık bütçeye rağmen ekonomik dengenin sağlanabileceği ve devletin gerekirse borçlanma ile açıkları kapatabileceği yönündeki görüşleri ülkemizde de kabul görmüştür. Bu nedenle bütçe açıkları ve kamu borç stoku kontrol edilemez boyutlara ulaşmıştır. Bütçe açıklarının birçok makroekonomik etkisi vardır. Açıkların ekonomi üzerindeki etkisi kriz dönemlerinde daha fazla görülmektedir. Bütçe açıkları ülkemizde özellikle 1990'lı yıllardan sonra ciddi bir sorun haline dönüşmüştür. Açıkların kapatılamamasında yaşanan en önemli sorunlar, yanlış finansman teknikleri ve ekonomik istikrarla beraber siyasi istikrarında olmayışıdır.

Kriz dönemlerinde uygulanan istikrar paketlerinin başarısını ölçmek için ilerleyen yılların bütçe gerçekleşme rakamları ve diğer ekonomik verilerini incelediğimizde, bazı istikrar paketlerinin açıkları kapatmada yetersiz kalıp başarısız olduğu, bazı paketlerinde daha başarılı olduğu görülmektedir. Bu çalışmada Türkiye'de kriz dönemlerinde bütçe açıklarının kapatılmasında istikrar paketlerinin rolü incelenecektir.

\section{Bütçe Açıkları ( Teorik Çerçeve)}

Devlet için çok mühim olan bütçenin genel olarak iki kalemi olan gelir ve giderler her zaman denk olmayabilir. En genel tanımı ile bütçe açıkları gelir ve harcamalar arasındaki negatif farktır (Kharas ve Mishra, 2003: 61). Bütçe açıklarını hesaplamak için çeşitli ölçüler ortaya konulsa da farklı değerlendirme ve hesaplama tekniklerinin oluşu bütçe açıklarının hesaplanmasını karmaşık bir hale getirebilmektedir (Kharas ve Mishra, 2003: 61). Bu yüzden kamusal açıklar ele alınırken çeşitli ölçüm teknikleri geliştirilmiştir.

Geleneksel bütçe açığı, bir ekonomide belli bir dönemde iç ve dış borç stoklarındaki değişmeler hesaba katılmaksızın, toplam kamu harcamaları ve toplam kamu gelirleri arasındaki farktır (Şen vd, 2007: 1). Kısacası borçlardaki değişimler dikkate alınmaksızın dışarıda tutularak hükümetin toplam gelir ve giderleri arasındaki farktır (Egeli, 2002:30). Geleneksel açığın faiz ödemelerini de içine alması ve enflasyondan kayda değer derecede etkilenmesi yanlış değerlendirmelere yol açan diğer bir sebeptir. Bu gibi olumsuzlukların 
ortadan kaldırılması ve ülkeler arasında karşılaştırma yaparken daha sağlıklı veriler elde edilebilmesi için geleneksel açık yerine Kamu Kesimi Borçlanma Gereği (KKBG) bir gösterge olarak kullanılmaktadır (Şen vd, 2007: 2).Konsolide bütçe açığı, mali yılbaşında genel bütçe tahmini gelirleri ve katma bütçe ${ }^{2}$ tahmini gelirlerinin, söz konusu idarelerin bütçe dönemi boyunca üstlenecekleri tahmini giderleri karşılayamaması durumunda oluşan açıktır (Altuğ, 1994: 193).

Birincil açık (Faiz Dışı Fazla), mevcut borçların faizleri için yapılan ödemeler çıkarıldıktan sonra bütçedeki dengeye bakmamıza imkân sağlar. Faiz ödemeleri hariç tutularak gelirlerin harcamaları karşılama oranı elde edilir ve bu oranda hükümetlerin bütçeler üzerindeki kontrol edebilecekleri kısımdır (Cansız, 2006: 69). Borç stokunun, borçlanma faizlerinin yüksek olduğu ve borcun döndürülmesi konusunda bazı risklerin bulunduğu gelișmekte olan ekonomilerin çoğunda faiz dışı fazla, maliye politikasının başarısında bir ölçüt olarak kabul edilmektedir (Aytaç, 2006: 149).

Enflasyonist bir ortamda geleneksel açık tanımlarının eksiklerinin fark edilmelerinden sonra alternatif ölçümler ortaya konmuştur. Bunlardan birisi işlemsel açıktır. İşlemsel açık kısaca; geleneksel açıktan faiz ödemelerinin fiili enflasyondan aşınan kısmının düşülmesi veya birincil açığa faiz ödemelerinin reel kısmı yani reel faiz ödemeleri eklenmek suretiyle elde edilebilir. Bu tanımlamanın ekonomik temeli şu varsayıma dayanır; enflasyon kaynaklı faiz ödemeleri amortisman ödemelerinin etkilerine benzemektedir. Geleneksel açık, amortisman ödemelerini, açık hesaplamaları yapılırken dışarıda tutar. İşlemsel açık kavramı ise borç faiz ödemelerinin enflasyonla ilgili kısmını da ele almaktadır (Tanzi vd, 1987: 18-19).

Reel açık ve nominal açık kavramları da yine enflasyonun yüksek olduğu ülkelerde önem arz etmektedir. Nominal bütçe açığı, kamu harcamaları ve kamu gelirlerinin nominal değerleri arasındaki negatif farkı ifade ederken, bu harcama ve gelirlerin reel değerleri arasındaki negatif fark ise reel bütçe açığını vermektedir. Enflasyon arttıkça bu iki açık arasındaki fark büyümektedir. Enflasyonun yüksek olduğu ülkelerde ise nominal bütçe açığı rakamlarının kullanılması, gerçek bütçe açığı rakamlarını verememektedir. Reel bütçe açığı hesaplamalarıyla, enflasyonun bütçe açıkları üzerinde meydana getirdiği olumsuzluk giderilmektedir (Şen vd, 2007: 24). Ekonomi tam istihdam düzeyine ulaştıktan sonra ortaya çıkan bütçe açığı türüne yapısal açık denmektedir. Konjoktürel açık ise iktisadi dalgalanmalara bağlı olarak ortaya çıkan açıktır. Konjonktürel açık iktisadi dalgalanmaların bütçe açığı üzerindeki etkisini ortaya koymaya çalışmaktadır (Şen vd, 2007: 29).

\subsection{Bütçe Açıklarına Yönelik İktisadi Yaklaşımlar}

Klasik iktisadi yaklaşım, bütçe harcamalarının olabildiğince az olmasını ister. Bu ekole göre vergiler, tarafsız ve nötr olmalı, yani ekonomideki birimlerin karar alma süreçlerini etkilememelidir. Bütçe ile ilgili en önemli yaklaşımları "bütçe denkliğidir" (Tüğen, 2009:

\footnotetext{
${ }^{2}$ Konsolide bütçe, 5018 sayılı Kamu Mali Yönetimi ve Kontrol Kanunundan önce genel bütçe ve katma bütçeden oluşmaktaydı. 1050 sayılı Muhasebe-i Umumiye Kanununun 115.maddesine göre "Giderleri özel gelirlerle karşılanan ve genel bütçe dışında tutulan bütçelere katma bütçe denir" hükmüne yer verilmiştir. İște 5018 sayılı KMYKK ile katma bütçe kavramı yürürlükten kaldırılmış ve yerine "Özel Bütçe" kavramı getirilmiştir.
} 
354/355). Neo-Klasik yaklaşım bütçe açıklarını analiz ederken bütçe açıklarını geçici ve sürekli olmalarına göre iki farklı şekilde analiz etmektedir. Eğer bütçe açıkları geçici ise bu açık makroekonomik değişkenler üzerinde çok küçük değişikliklere sebep olacaktır. Bu açıklar özel tasarrufları teşvik bile edebilir. Ancak bütçe açıları süreklilik arz ederse, tasarrufları da olumsuz etkileyip ekonomide yapısal aksaklıklara sebep olacaktır (Şen vd, 2007: 42).

Bütçenin denk olması yerine ekonominin genel dengeye sahip olmasını öne süren modern ekonomik anlayış ve Keynesyen talep yönlü politikalar, hem gelişmiş hem de gelişmekte olan ülke ekonomilerinde açık ve borç sorunlarının artmasına neden olmuştur. Keynesyen politikalara göre bütçe denkliği yerine makroekonomik denge sağlanmalıdır ve gerektiğinde devlet borçlanmaya başvurmalıdır. Ancak borçlanmanın olası olumsuz etkileri göz ardı edilerek bütçe açıklarının finansmanında yoğun olarak kullanılması açık-borç dinamiğini bozmuş ve kamu açıklarının çok hızlı bir şekilde artması ile borç stoklarındaki önlenemez yükselişler, geleneksel maliye politikalarının sorgulanmasına yol açmıştır (Yıldırım ve Özcan: 2011: 39).

Monetarist iktisadi düşüncenin bütçe konusundaki temel prensibi; bütçe denk olmalıdır. Ancak bütçe açıklarının nereden ve hangi şartlar altında finanse edildiği, bu açıkların enflasyonist olup olmadıklarını belirleyen temel faktördür (Şen vd, 2007: 50-51). Kamu tercihi teorisinin bütçe noktasındaki görüşleri denk bütçe etrafında yoğunlaşmıştır. Buchanan bunu açıklarken politik başarının sağlanmasında, açık bütçe politikasının dlaha etkin olduğunu da göz ardı etmez. Buna göre eğer politik başarı temel amaç ise, burada harcamalar politikası önemli olacak ve hedeflenen başarı kolaylıkla elde edilebilecektir. Fakat denk bütçe politikası ise gerek politikacılar gerekse vatandaşlar açısından daha az maliyetli olacaktır (Buchanan ve Tollison, 1984: 241).

\section{2, Bütçe Açıklarının Nedenleri}

Bütçe açıklarının nedenleri incelenirken kamu kesiminin bu noktada etkinliğinin önemi büyüktür. Bütçe açı̆̆ı ile mücadele etmeye çalışan birçok hükümet, çözüm için ciddi adımlar atmaktadır. Ancak bazen yanlış müdahaleler, tedbirler veya yönetimin bizzat kendisinden kaynaklanan eksiklikler bu açıkların artmasına yol açmaktadır. Bütçe açıklarının oluşmasında siyasal karar alma süreçleri etkili olmaktadır. Harcamaları artırmak, siyasal iktidar için her zaman daha kolaydır, çünkü siyasal rant sağlanmaktadır. Fakat açığın finansmanına yönelik adımlar siyasal risk taşımaktadır. Örneğin açıkların finansmanında kullanılan vergilerin artırılması kolay bir yöntem değildir. Öncelikle yasal düzenlemeler gereklidir ve mevcut vergilerin artırılması veya yeni vergiler konulması, yasalaşsa bile bu noktada siyasal iktidar ciddi bir vergi direnci ile karşılaş1labilir. Siyasal iktidar bu kısımları atlatsa bile seçim sürecinde ciddi bir risk almış olacaktır. Dolayısıyla tam tersine harcamaların artırılması siyasal rant sağlayacak; fakat, bütçe açıkları büyümeye devam edecektir. (Pınar, 2010: 138).

Yıllarca hemen hemen aynı çizgide yürütülen "Keynesyen İktisat Politikaları” çerçevesindeki bütçe denkliği politikaları ekonomik ve mali istikrarı bozmuş ve siyasal iktidarlar gerek durumu iyileştirebilmek gerekse siyasal rant uğruna bütçe denkliğinden sürekli tavizler vermişlerdir. Günümüzde gelişmiş ülkelerin birçoğunda özellikle sosyal güvenlik hizmetlerine ayrıca önem verilmektedir. Bunun için bütçeden sosyal harcamalara ayrılan payda giderek artmaktadır. Ayrıca keynesyen iktisat politikalarına göre sosyal devlet yatırımları teşvik eder ve refah arttıkça ekonomik büyüme devam eder. Ancak artan sosyal harcamalar aynı hızda finanse edilmediğinden bütçe açıklarını artırmaktadır (Şener, 2008: 
395). Silahlanma yarışının ve savaş tehdidinin her geçen gün arttığı günümüzde savunma hizmetlerinin tüm ülkeler için ayrı bir öneme sahip olması savunma harcamalarının artmasında belirleyici bir etken olmaktadır. Savunma harcamalarının düzeyini ve dağılımını belirleyen çeşitli faktörler bulunduğundan dolayı, savunma harcamalarının miktarı ve talebi sadece güvenlik ile açıklanamaz (Giray, 2004: 196). Sadece savaşlar değil, savaş sonrası maddi ve manevi kayıplarında giderilmesi için çok büyük kaynaklar kullanılmakta ve bütçe açıkları artmaktadır (Şen vd, 2007: 69).

Gelişmekte olan ülkeler pek çok ekonomik problemle karşı karşıyadır. Yaşam standardını artıran, sürekli bir yüksek büyüme oranını gerçekleştirmede birçoğu başarısız olmaktadır. Yüksek enflasyon oranı ve finansal yetersizlikler, yatırımların gelişmekte olan ülkelere çekilmesini engellemektedir. Hükümetler bu sorunların çözümü için kaynak ihtiyaçlarını iç ve diş borçlanmalar yaparak çözmeye çalışmaktadırlar. Ancak pek çok ülke diş borçlarla ilgili problemlerden kaçınmak için dış borçlanmadan kaçınabilir. Bu yüzden bütçe açıklarını kapatmada iç kaynaklara daha çok başvurabilirler (Feltenstein ve Iwata, 2002: 3-4). Ülkeler daha büyük borç ve açık problemleri yaşadıkça bunu para genişlemesi yoluyla geçici bir süreliğine çözmekle beraber, faiz oranları ve enflasyonun artmasına da sebep olmuşlardır. Sonuç olarak kısır bir döngüye dönüşen borçlanma, borç ödemeleri ve bunlarla beraber bütçe açığı problemi o ülkeler için içinden çıkılmaz bir hale dönüşmüştür (Eliana ve Albert, 1990: $331)$.

Faiz ödemelerindeki artışlar nedeniylede bütçe açıkları artmaktadır. Bu durum ise sağlıklı bir mali yapının oluşturulamamasıyla beraber, parasal ve ekonomik disiplinin sağlanamamasına dolayısıyla sistemde bir "mali disiplinsizlik" probleminin çıkmasına neden olmaktadır (Kesik, 2003: 89).

Bütçe açıklarının temel ekonomik nedenleri yukarıdaki açıklamalar 1şığında şu şekilde siralanabilir;

- $\quad$ Ekonomik istikrarsızlıklar,

- Hükümetlerin merkez bankalarından karşılıksız borçlanmaları,

- $\quad$ Enflasyon,

- $\quad$ İç ve dış borçların anapara ve faiz ödemeleri,

- $\quad$ Ekonomide piyasanın yetersizliğinden dolayı devletin piyasada bulunma çabası,

- $\quad$ Mali disiplini sağlamada isteksizlik veya başarısızlık,

- Konjonktürel dalgalanmalar,

- Vergi gelirlerinin yetersiz oluşu ve vergi toplamadaki düşük başarı oranı,

- $\quad$ Ekonomik krizler.

- $\quad$ Kriz ortamlarında uygulamaya konulan istikrar paketlerinin uygulanamaması.

Yapılan analizler göstermiştir ki genel bütçe gider tahminleri ile genel bütçe gider gerçekleşme rakamları arasındaki fark, koalisyon hükümetleri dönemlerinde tek partili 
hükümet dönemlerine göre artmaktadır ve bu fark tesadüfî değil sistematiktir (Aslan ve Bilge, 2009: 285).

Ekonomik krizler etkiledikleri sektörler bakımından iki temel gruba ayrılabilir; reel sektör krizleri ve finansal sektör krizleri. Reel krizler, üretimde veya istihdamda önemli daralmalar şeklinde ortaya çıkarken, finansal krizler ekonominin reel kesimi üzerinde tahrip edici etkiler meydana getirebilen ve piyasaların etkin işleyiş gücünü bozan finansal piyasa çöküşleridir. Her iki durumda da görülmesi muhtemel ortak nokta, bütçe açıklarının artış gösterebilmesidir. Örneğin bir reel krizde istihdam daralmasını çözebilmek için hükümet, yatırımları arttırmak isteyecek ve bu durum bütçe açıklarının artmasına sebep olabilecektir (Delice, 2003: 58).

\subsection{Bütçe Açıklarının Makroekonomik Etkileri}

Bütçe açıkları bir ekonomide genellikle uzun vadede makroekonomik etkiler ortaya çıkarmaktadır. Uzun yıllar bütçe açığı veren ekonomilerde, insanların beklentileri olumsuz yönde etkilenmektedir. Dolayısıyla milli gelirden yatırımlara, özel tasarruflardan gelir dağılımına kadar birçok makroekonomik büyüklük bütçe açıklarına bağlı olarak olumsuz yönde etkilenmektedir. Bütçe açıklarının ekonomik büyüme üzerindeki etkisinin doğrudan mı veya dolaylı mı olduğu tartışmalı bir konudur. Ancak bir çok ampirik çalışmada bütçe açıklarının artışının ekonomik büyümeyi olumsuz etkilediği ortaya koyulmuştur (Şen vd, 2007: 119).

Bütçe açıklarının birçok etkisi olmakla beraber, bu etkilerin çoğunun ortak sonucu, ulusal tasarrufların azalmasıdır. Ulusal tasarruf ise özel ve kamu tasarruflarının toplamından oluşmaktadır. Kamu kesiminde bütçe açığı söz konusu olduğu zaman, kamu tasarrufları özel tasarrufların altına inerek negatif olur. Kamu tasarruflarında ortaya çıkacak bir azalışa karşın, özel tasarruflarda o azalışa kısmen denk gelebilecek bir artış olacaktır. Örneğin vergilerdeki 1 TL'lik bir azalma olsun, bu indirim kamu tasarruflarının 1 TL azaltmasına karşın, aynı zamanda hane halkının vergi sonrası özel tasarrufları da 1 TL artacaktır. Muhtemelen hane halkı bu beklenmedik paranın bir kısmını harcayabilir ve bir kısmını da tasarruf edebilir (Ball ve Mankiw, 1995: 3).

Sonuç olarak; bütçe açıkları meydana geldiği dönemde kamu harcamaları arttığından, bu özel tasarruf ve yatırımları artırabilir. Ancak, bütçe açıklarının kapatılmasına yönelik tedbirler alındığında tasarruf ve yatırımlar azalacaktır. Örneğin; vergi oranları artırılarak veya ek vergiler getirilerek bütçe açığının kapatılmaya çalışılması sonucu, özel yatırımlar azalacaktır.

Bütçe açıkları eğer iç borçlanma ile finanse edilmişse, sermaye piyasasında kamu kesiminin fon talebini artırıp, piyasadaki fon yapısını bozup faiz oranlarını yükseltmektedir. Faiz oranları yükseldiğinde firmaların ve tasarruf sahiplerinin tasarruf ve yatırım kararları değişmektedir. Fon piyasasında bulunan mevcut kaynaklar kamu borçlanma senetlerine aktarıldığında, özel kesim yatırımları için fon sıkıntısı yaşayacaktır. Yaşanan fon sıkıntısı faiz oranlarını artıracaktır (Sak, 1995: 37). Kamu açıkları eğer dış borçlarla finanse edilirse, açıklar dış ödemeler dengesi üzerinde doğrudan bir etki oluşturacaktır. Ancak, açıklar iç borçlanma ile finanse edilirse faiz oranları ve döviz kurları üzerinde dolaylı bir etki meydana gelecektir. Bütçe açıklarını kapatmak için hükümet tarafından iç borçlanmaya gidilirse bunun ilk makroekonomik etkisi faiz oranlarının artması şeklinde olacaktır. Piyasada atıl fon bulunmadığında, tasarrufların yatırımlardan küçük olduğu koşullarda, yeni borç bulabilmek için neredeyse tek yol faiz oranlarını artırmaktır. Ülkemizde de kamu açıklarının kapatılması için yapılan iç borçlanmalar faiz oranlarını artırmıştır (Sonat, 1994: 123). 
Bütçe açıklarının sonuçları arasında enflasyonla ilgili olanlarını üç şekilde gerçekleşebileceği söylenebilir. İlki kamu açığı doğrudan talep genişletici bir etki meydana getirebilir. Kamu açıkları, kamu harcamalarının kontrolsüz bir artışından kaynaklanıyorsa ve ekonomide çarpan etkisi yüksekse, üretimle karşılanamayan talep fazlası, enflasyonist baskıya neden olabilir. İkinci ve üçüncü sonuçlar, kamu açığının finansman biçimi ile ilgilidir. Kamu açıkları ağırlıklı olarak tahvil ve bono gibi iç finansman yoluyla finanse ediliyorsa, reel tasarruf hacmi sınırlı olan bir ekonomide, kamu kesiminin iç piyasadan bu ek talebi maliyet yönlü enflasyonist bir baskıya neden olabilir. Ancak kamu açıkları daha çok emisyon ile karşılanıyorsa doğrudan enflasyon artışı beklenir. Çünkü para arzındaki kontrolsüz artış, fiyatlar genel düzeyini artıracaktır. (Erol, 1997: 173).

Birçok ülkede yapılan çalışmalarda, Merkez Bankasının siyasi iktidara çok sıkı bağlı olduğu durumlarda, siyasal iktidarlar Merkez Bankası kaynaklarına sık sık başvurmaktadır. Böyle ülkelerde enflasyon oranının daha yüksek olduğu söylenebilir. Kamu kesimi açıklarının da kapatılmasında Merkez Bankası kaynaklarına başvurulması en kolay yollardan biridir. Ancak bu durum enflasyonu artıracaktır. Çünkü kamu kesimi açıkları monetize edildiği noktadan itibaren enflasyonist bir sürecin içine girilmeye başlanmıştır (Demir vd, 2005: 252).

\subsection{Bütçe Açıklarının Finansman Yöntemleri}

Devletin gelir ve giderleri arasında ortaya çıkan farkları kapatmanın çeşitli yöntemleri vardır. Yukarıda da belirtildiği gibi Hazinenin Merkez Bankasından borçlanması ya da monetizasyon dediğimiz yöntem hükümet için en kolay finansman şekillerinden biridir. Çünkü borç verende borç alanda kendi hiyerarşisine tabi kurumlardır. Bu finansman yönteminin çoğu kez rahatlıkla ilk başvurulan kaynak olması makroekonomik dengeleri bozmuştur. Kamu gelir ve giderlerini kapatabilmek için devlet çeşitli şekillerde borçlanabilir. Kamu kesimi açıkları finansmanının temel olarak dört şekli vardır; para basımı, döviz rezervlerinin kullanımı, diş borçlanma ve iç borçlanma. Para basmak yoluyla hükümet gelirleri, açık finansmanın bir kaynağı olarak tanımlanır. Aslında her bir finans şekli bir ekonomik dengesizlikle eşleştirilebilir. Para basımı yani monetizasyon ile enflasyon, döviz rezervlerinin kullanımı ile döviz krizlerinin başlangıcı, dış borçlanma ile dış borç krizleri, iç borçlanma ile yüksek reel faiz oranları ilişkilendirilebilir (Fischer ve William, 1990: 131).

Bütçe açıklarının aşırı büyümesi istenilen bir durum değildir. Kısa dönemde bütçe açıklarını istikrara kavuşturmak mümkün olmadığından, hükümetler daha hızlı çözüm yollarına başvurmayı deneyeceklerdir. Çünkü mali istikrarın sağlanması cari bütçe açığının kapatılmasına göre çok daha uzun bir zaman diliminde gerçekleşmektedir. $\mathrm{Bu}$ yüzden hükümetler kendilerine daha hızlı kaynak bulabilmek için farklı finans yöntemlerine başvurmaktadır.

Bütçe açığı söz konusu olduğunda devletin borçlanması beklenir. Hükümet bunu iki şekilde yapabilir; ya halktan borçlanarak ya da Merkez Bankasından borçlanarak. Hükümetin ikinci yöntemi seçmesi durumunda parasal finansman yöntemi söz konusudur ve Hazine, Merkez Bankasına menkul kıymet satarak borcun monetizasyonunu gerçekleştirecektir. Merkez Bankası da satın almış olduğu borçları finanse etmek için parasal tabanda genişleme yapacaktır. Parasal tabanın artması faiz oranlarını düşürecektir. Ancak bu durumda fiyatlar genel düzeyinin artması beklenmektedir. Çünkü para arzının artması toplam talebi arzdan daha fazla artırarak fiyat düzeyinin artmasına vesile olacaktır (Ataç, 2009: 253).

1211 Sayılı Merkez Bankası kanunun 50.maddesine göre banka, miktarı cari yıl genel bütçe ödenekleri toplamının \%15'ini geçmemek üzere Hazineye kısa vadelii bir avans hesabı 
açmaktadır. 25.04.2001 tarihine kadar bu avans hesabına uygulanacak faiz haddi ile ekonomik durum göz önünde tutularak kullanılacak avans nispeti Maliye Bakanlığı ile Banka arasında kararlaştırılırdı. Ancak Banka'nın temel amacını gerçekleştirebilmesi ve para politikasının etkin bir şekilde yürütülebilmesi için, Hazine'ye kısa vadeli avans verilmesine ilişkin 50 . madde ile kamu müesseselerine kredi sağlanmasına ilişkin 51 inci madde 25.4.2001 tarihli ve 4651 sayılı kanun ile yürürlükten kaldırılmıştır. Böylece, Maastricht Anlaşması'nın 104 üncü maddesi ve Avrupa Merkez Bankaları Sistemi Statüsü'nün 21.1 maddesi ile uyum sağlanmış, Merkez Bankası'nın bağımsızlık derecesi artırılmıştır.

Kamu borçlarını süreleri bakımından sınıflandırırken en çok kullanılan yöntem kısa vadeli ve uzun vadeli borç ayrımıdır. Devlet aldığı borcu, yaptığı ekonomik planlara göre çeşitli şekillerde geri ödemektedir. Bu vade süresi 1 yıldan az veya 1 yıldan uzun sürmesine göre farklı isimlendirilmektedir. Buna göre; vade süresi 1 yıldan az olan borçlar "kısa vadeli borçlar", 1 yıldan daha uzun sürede ödenen borçlar "uzun vadeli borçlar" olarak sinıflandırılabilir (Ulusoy, 2006: 40).

Devletin normal borç kaynağı iç borçlardır. Ancak iç piyasanın bu borcu karşılayacak gücü olmadığı takdirde diş borca başvurulur. İç borçlanma milli gelir üzerinde herhangi bir değişikliğe sebep olmaz. Çünkü borçlu ve alacaklı aynı ekonomik sistemin bir parçası olduklarından sadece milli gelirin yapısı ve dağılımında kayda değer değişiklikler olmaktadır. Devletin iç piyasadan borçlanması dış borçlanmaya göre daha kolay olduğundan, devlet borçlarının büyük bölümü iç borçlardan oluşmaktadır (Ulusoy, 2006: 53). Devletin borçlanabileceği iç kaynakları aşağıdaki gibi sıralayabiliriz (Pehlivan, 2006: 191); Bireyler, Merkez Bankası, Kamu Kurum ve Kuruluşları, Bankalar. Ülkemizde 2001 yılında 1211 sayılı Merkez Bankası Kanununda yapılan değişiklik ile Merkez Bankasının her yıl bütçe ödeneklerinin toplamının belli bir oranı kadar Hazineye kısa vadeli avans verme yetkisi yürürlükten kaldırılarak ekonomik kriz dönemlerinde krizi derinleştiren bir uygulamanın önüne geçilmiştir.

\section{Türkiye’de 1990 Sonrası Ekonomik Krizler Ve Bütçe Açıkları}

Son y1llarda dünyada ve ülkemizde yaşanan küresel ve ulusal ekonomik krizler, gelişmiş ve gelişmekte olan ülkeleri ekonomik büyüme, istihdam ve bütçe açıłkları gibi birçok makroekonomik ölçü açısından etkilemektedir. Ülkemizdeki krizlerin başlangıcını 1929 yılı Büyük Bunalımından başlatmak mümkündür. 1929'dan bu yana iç ve dış ekonomik dengelerden kaynaklanan birçok krizle karşı karşıya kalındığı malumdur. Ancak çalışmanın bu bölümünde yakın tarihimizde, özellikle 1990 yılından sonra yaşanan ve etkisi diğerlerine göre daha çok hissedilip daha uzun süre devam eden krizlere değinilecektir.

\subsection{Krizi ve 5 Nisan Kararları}

1980'li yılların ikinci yarısından itibaren kamu açıkları hızla artmış ve 1988 yılında \%4,8 olan KKBG/GSMH oranı 1993 yılında \%12'lere kadar yükselmiştir. Kamu açıklarındaki artış, talep baskısını beraberinde getirmiş ve reel büyüme hızı artmıştır. Büyüme hızındaki inişli çıkışlı istikrarsız ilerleme makroekonomik dengelerin bozulmasına neden olmuştur. 1992 yılında dış ticaret açığı 8,2 milyar dolardan 14,2 milyar dolara yükselmiştir (Öçal, 2005: 186). Krize giden süreçlerde önemli adımlardan biri de Hazinenin Merkez Bankası kaynaklarını kullanmasını sağlayacak kısa vadeli avans miktarının artırılmasıdır. Bu yöntem hükümetler 
için en kolay başvurulabilecek kaynak niteliğinde olup, ekonomide uzun dönemde gerek bütçe dengesi gerekse enflasyon ve diğer ekonomik göstergeleri olumsuz etkilemektedir.

Grafik 3.1. 1988-1998 Döneminde GSMH ile Tarmm ve Sanayi Sektörlerindeki Büyüme Oranlan (\%)

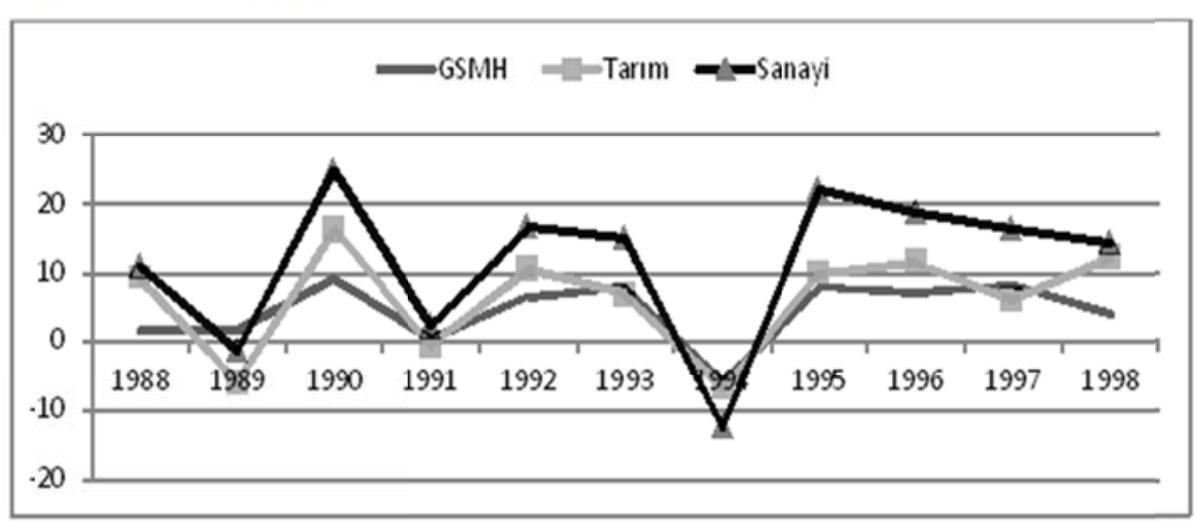

\section{Kaynak: TüİK ve DPT}

1994 Krizinin etkisine sektörel olarak bakıldığında, büyüme hızlarında ciddi bir düşüşü görmek mümkündür. Özellikle yıllar itibariyle genel trende bakıldığında tam manasıyla bir istikrarın sağlanamadığı ve ekonomideki istikrarsızlıkların derinleştiği gözlenmektedir. Ayrıca 1994 Krizi TÜFE ve ÜFE oranlarını da negatif olarak etkilemiştir. Bu oranlar 1987 yılından itibaren belli bir seviyede ilerlerken, 1993'ten itibaren ciddi olarak artmıştır.

\section{Grafik 3.2. 1985-1995 Ylllan Arasm da TÜFE ve ÜFE Yılsonu Değerleri (\%)}

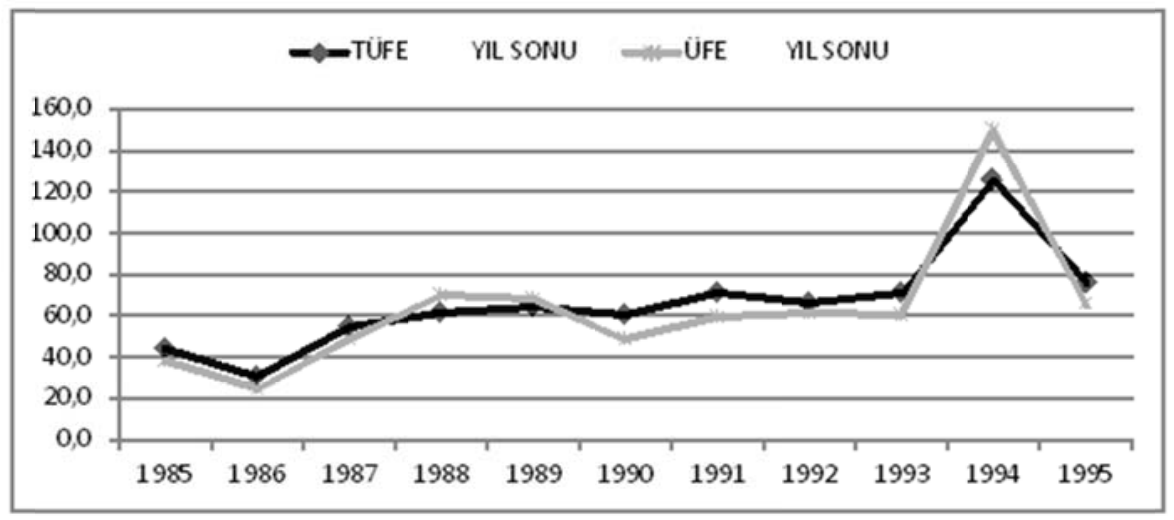

Kaynak: Merkez Bankası ve Hazine Müsteșarlğg

Grafik 3.2'de görüldüğü gibi 1994'ten önce, önemli bir ekonomik gösterge olan TÜFE ve ÜFE oranlarında yüzdelik olarak ciddi artışlar yaşanmaya bașlamıștır. 1986' da ÜFE \%24, TÜFE \%30 civarlarında iken 1994'e gelindiğinde ÜFE oranı \% 149'a ve TÜFE oran1 \% 125'e kadar yükselmiştir. Yüksek oranlı fiyat artışları hükümetin de harcamalarını artırmıştır. Çünkü böyle kriz ortamları, gerek paranın uğradığı değer kaybından dolayı, gerekse hükümetlerin, halka asgari bir geçim standardı sunmak için sosyal harcamaları artırmalarından dolayı, kamu harcamaları artmaktadır.

İstikrar programı, enflasyon oranını azaltma, TL'ye kararlılık kazandırma, ihracatı artırma ve bunları gerçekleştirerek, "sürdürülebilir" bir ekonomik ve toplumsal gelişme sürecini elde etmeyi amaçlamıştır. Bu amaçlara ulaşılması için, başta kamu kesimi açıkları azaltılarak bir 
dizi yapısal yeni düzenlemeler gerçekleştirilmek istenmiştir. 5 Nisan kararları "temel ilke" olarak "üretim yapan, sübvansiyon dağıtan bir devlet yapısından, ekonomide piyasa mekanizmasının tüm kurum ve kurallarıyla işlemesini sağlayan ve sosyal dengeleri gözeten bir devlet yapısına geçmeyi” kabul etmiştir (DPT, Ekonomik Önlemler Uygulama Paketi, 1994).

Ekonomik istikrar programları uygulanacak önlemlerin kapsamı ve uygulama süreleri bakımından "şok tedavisi" veya "aşamalı tedavi" olarak ikiye ayrılabilir. İsminden de anlaşılacağı üzere şok tedavisinde istenen sonuçlara en kısa sürede ulaşılmak istenir. Bir diğer ayrım ise Ortodoks ve Heterodoks istikrar önlemleridir. Ortodoks istikrar önlemlerinin iki temel amacı vardır. Yüksek enflasyonun hızlı ve kalıcı bir şekilde aşağı çekilmesi ile dış dengenin sürekli iyileştirilmesidir. Heterodoks programlar ise, ücret ve fiyatlara istikrar kazandıracak bir kontrol sistemi getirerek mali disipline oldukça önem vermektedir. Kronik enflasyonun yaşandığı ülkelerde Heterodoks programların daha başarılı olduğu söylenebilir. İşte bu tanımlar çerçevesinde 5 Nisan Kararları, kısa vadede ortodoks-şok tedavisi öngören, uzun dönemde ise heterodoks-aşamalı politikalar içeren karma bir yapıya sahiptir. Örneğin; kamu kesimince üretilen mal ve hizmetlere çok yüksek oranlarda ani olarak zam yapılmakla beraber kamu harcamaları \% 30 seviyelerine kadar kısılmıştır (Şahin, 2007:224- 225).

5 Nisan Kararları kısa vadeli politika önlemlerinden yapısal düzenlemelere kadar çok kapsamlı olmasına rağmen, iç ve diş baskılar sonucunda uygulamadan ziyade bir plan olarak kâğıt üzerinde kalmıştır. Bu kararları Karluk (2007) "popülist” yanı ağır basan bir önlemler demetidir diye tanımlamaktadır. Ancak şunu da belirtmek gerekir ki, 1994 krizinden her ne kadar o dönemki hükümet sorumlu olsa bile, önceki birkaç hükümetinde popülist uygulamalarını göz ardı etmemek gerekir. 1989 yılından bu yana hükümetler gerek iç finans problemlerini çözmek gerekse büyüme oranını yükseltebilmek için sık sık dış borçlara başvurmaktaydılar (Aydın, 2005: 116).

5 Nisan Kararları ve 5 Nisandan sonra mevcut kararlar çerçevesinde alınan kararları ve kararların bazı sonuçlarını aşağıdaki gibi sıralamak mümkündür (Karluk, 2007: 426);

- $\quad$ Türk Lirası \% 39 oranında dış değer kaybına uğramıştır,

- Hazine bonosu, tahvil ve repo gelirlerinden alınan \% 5 vergi kaldırılmıştır,

- Bankalar topladıkları paraların belirli bir kısmını devlete munzam karşılıklar şeklinde

vermek zorundaydılar, bu oran sıfirlanmıştır,

- $\quad$ Bir defaya mahsus olmak üzere ek vergiler getirilerek 70 trilyon liralık ek gelir elde edebilmek hedeflenmiştir,

- $\quad$ TL cinsinden tasarruf mevduatı ve döviz tevdiat hesaplarının sigorta kapsamı önce yükseltilmiş daha sonra sınırsız hale getirilmiştir,

- $\quad$ 1984'ten sonra ilk defa IMF ile destekleme düzenlemeleri yapılmaya başlamıştır,

- $\quad$ KİT ve TEKEL ürünlerine büyük oranlarda zamlar yapılmıştır,

- $\quad$ Akaryakıt ürünlerindeki \% 10'luk kesintiler \% 25'e çıkarılmıştır,

- İstikrar programında Nisan-Haziran döneminde 16.3 trilyon TL ilave gelir sağlanması, bütçe harcamalarında 22 trilyon TL tutarında kısıntıya gidilmesi, bütçe açığında 38 trilyon TL tutarında iyileşme sağlanması ve bütçe açığının bu üç ay için 10 trilyon TL'ye indirilmesi hedeflenmiştir.

- $\quad$ Hazinenin merkez bankasından alacağı avans, bütçe ödenek artışının \%12'si ile sınırlandırılmıştır. Bu oran 1996-1997-1998 yıllarında sırasıyla \% 10 - \% 6 - \% 3 şeklinde uygulanacağı karara bağlanmıştır 
Kamu Maliyesi açısından ele alınacak en önemli ölçülerden birisi de bütçe açıklarıdır. 5 Nisan kararlarının en önemli hedeflerinden birisi de bütçe açıklarını kapatıp KKBG'nin GSMH'ya oranını \% 6,2'ye indirebilmekti. IMF de Konsolide bütçe açığına 109,6 trilyon TL üst limit koymasına rağmen bu rakam tutturulamamıştır. İlk birkaç ay bütçe açığı azalmaya başlasa da Eylül ayından itibaren vergi, fon ve özelleştirme gelirlerinde istenilen artışların sağlanamaması ve harcamaların hızlı artış eğiliminde olması, bütçe açığının büyümesine neden olmuştur (Öçal, 2005: 204).

Tablo 3.1. 1991-1997 Ylları A rasında Bazı Ekonomik Büyüklükler

\begin{tabular}{|c|c|c|c|c|c|c|c|}
\hline & 1991 & 1992 & 1993 & 1994 & 1995 & 1996 & 1997 \\
\hline $\begin{array}{l}\text { Konsolide Bü tçe } \\
\text { Giderleri (Bin } \\
\text { TL) }\end{array}$ & 132.401 & 225.398 & 490.438 & 902.454 & 1.724 .194 & 3.961 .308 & 8.050 .252 \\
\hline $\begin{array}{l}\text { Konsolide Bü tçe } \\
\text { Gelirleri (Bin } \\
\text { TL) }\end{array}$ & 99.085 & 178.070 & 357.333 & 751.615 & 1.409 .250 & 2.727 .958 & 5.815 .099 \\
\hline $\begin{array}{l}\text { Tüfe(Yul } \\
\text { Sonu) } \%\end{array}$ & 71,1 & 66 & 71,1 & 125,5 & 76 & 79,8 & 99,1 \\
\hline \begin{tabular}{|l}
$\begin{array}{l}\text { Ufe } \\
\text { Sonu) } \%\end{array} \quad$ (Yll \\
\end{tabular} & 59,2 & 61,4 & 60,3 & 149,6 & 65,6 & 84,9 & 91 \\
\hline $\begin{array}{l}\text { Bütçe } \\
\text { Dengesi/GSMH }\end{array}$ & $-6,3$ & $-5,6$ & $-9,1$ & $-5,7$ & $-6,1$ & $-11,8$ & $-11,3$ \\
\hline $\begin{array}{l}\text { Vergi } \\
\text { Gelirleri/GSM } \\
\text { H } \\
\end{array}$ & 12,4 & 12,8 & 13,2 & 15,1 & 13,8 & 15 & 16,1 \\
\hline KKBG/ GSMH & 7,5 & 7,9 & 7,7 & 4,6 & 3,7 & 6,5 & 5,8 \\
\hline $\begin{array}{l}\text { Toplam } \\
\text { KKBG(Bin TL) }\end{array}$ & 63.111 & 116.147 & 203.811 & 239.573 & 390.028 & 1.294 .178 & 2.258 .007 \\
\hline
\end{tabular}

Tablo 3.1'de görüldüğü gibi, gerek özelleştirme uygulamalarındaki başarısızlıklar gerekse vergi gelirlerinde istenen başarının elde edilememesi sonucu bütçe 1994 yılı sonunda yaklaşık 150 trilyon TL açık vermiştir. Hedeflerin birçoğunun tutturulmasında zorlanılmıştır. TÜFE ve ÜFE oranları 1994 yılı sonunda \%100 oranını bile geçmiştir. Reel sektör Cumhuriyet tarihindeki en büyük daralmalardan birini yaşamıştır ve ekonomi durgunluk sürecine girmiştir. Enflasyon oranı \% 150'ye ulaşarak yine başka bir rekor kırılmıştır. 1994'te ekonomide hem durgunluğun olması hem de enflasyonun yükselmesi anlamına gelen stagflasyonun yaşanması bir diğer problem olmuştur. Bunun yaşanmasında kamu harcamalarının kısılamaması ve kamu gelirlerinin istenilen şekilde artırılamamasının büyük etkisi olmuştur (Karluk, 2007: 427).

1994 yılında 4050 no'lu kanun 330 Kasım 1994 tarihinde resmi gazetede yayınlanmış ve 100 trilyon TL'lik ek bütçe çıkarılmıştır. Tütün, tütün mamulleri, tuz ve alkol işletmeleri genel müdürlüğünün görev zararlarının karşılanmaması kabul edilmiştir. Fakat bu tür kararların hiç biri istikrarı sağlayamamış ve ekonomideki kriz süreci devam etmiştir.

\footnotetext{
${ }^{3} 3941$ Sayılı 1994 Mali Yılı Bütçe Kanunu İle Bağlı (A) Ve (B) İşaretli Cetvellerde Değişiklik Yapılmasina Ve Bir Ek Madde Eklenmesine Dair Kanun.
} 
Sonuç olarak 5 Nisan Kararları ile istenen sonuca ulaşılamamıştır. Alınan kararların uygulanmasındaki kararlılığın ancak birkaç ay sürdüğünü görmek mümkündür. Kriz döneminde oldukça önemli olduğu vurgulanan sıkı maliye politikalarından tavizler verilmesi sonucu bütçe açıkları kontrol edilememiştir. Bütçe gelir kalemlerinde önemli artışlar görülebilmesine rağmen, giderlerdeki büyük artışlar ile iç ve dış borç faiz ödemeleri ve özelleştirme uygulamalarında istenilen neticeye ulaşılamaması bütçe açıklarının büyümesine neden olmuştur. 1994 Krizinden çıkış olarak görülen ve özellikle bütçe açıklarını kapatmaya yönelik tedbirlerin başarısız olduğu sonucuna ulaşmaktadır. Bütçe açıkları için sadece gelirleri artırma ve harcamaları kısmaya yönelik alınan tedbirlerin etkisinin kısa dönemli ve az olduğunu söylemek mümkündür.

\subsection{Kasım 2000 Ve Şubat 2001 Krizlerinde Bütçe Açıkları}

1994 yılında yaşanan büyük bir ekonomik krizden sonra ekonomi negatif bir şekilde ilerleyişini sürdürmüştür. Ancak tam olarak "ekonomik kriz" diye adlandırabileceğimiz ve büyük çapta olan krizler 2000 ve 2001 yıllarında yaşanmıştır. 17 Ağustos 1999 yılında yaşanan Marmara depremi zaten kötü giden bir ekonomide dengeleri iyice sarsmış ve bütçe açıklarının artmasına neden olmuştur. Ekonomi \% 6,1 oranında küçülmüş, enflasyon oranı \% 70’lere çıkmıştır. Bunlar gibi yaşanan birçok gelişme ekonomiyi bir uçuruma sürüklerken, ülkede bir taraftan da siyasi istikrarsızlıklar, kısa ömürlü koalisyon hükümetleri ve bunların bir sonucu olarak ekonomik açıdan etkisiz bir yönetim varlığını sürdürmekteydi.

\subsubsection{Kasım 2000 Krizi}

Kasım 2000'de ekonominin genel durumu şu şekilde özetlenebilir: Faiz oranları önemli ölçüde yükselmiş, yurtdışına büyük boyutlu bir sermaye çıkışı gerçekleşmiş, Merkez Bankası rezervleri hızla gerilemiş, hisse senedi fiyatlarında keskin bir düşüş gözlenmiş ve orta ölçekte bir banka sistem dışına alınmıştır. Krizin daha da derinleşmesini önlemek amacıyla Kasım ve Aralık aylarında bir dizi önlemler uygulamaya konulmuş olsa da bu önlemler ancak geçici bir iyileşme sağlayabilmiştir. Ancak, Şubat 2001'de Hazine ihalesi öncesindeki olumsuz gelişmeler uygulanan programa olan güvenin tamamen kaybolmasına neiden olmuş ve Türk Lirasına karşı bir spekülatif atak meydana gelmiştir. Tüm bu gelişmeler Kasım 2000 Krizini ve Şubat 2001 Kriz sürecini tetiklemiştir (BDDK, 2010: 20).

1 Ocak 2000'de yürürlüğe giren "Enflasyonla Mücadele Programı”n»n temel amacı 3. Maddede aşağıdaki gibi açıklanmıştır (Erçel, 2000: 1);

- $\quad$ Tüketici enflasyonunu, yapısal reformlarla desteklenen, birbirleriyle tutarlı, güçlü, itibarlı ve süreklilik arz eden maliye, gelir, para ve kur politikalarının eş güdümlü uygulanması ile 2000 yılı sonunda \% 25, 2001 yılı sonunda \% 12 ve 2002 yılında \% 7'ye indirmek,

- $\quad$ Reel faiz oranlarını makul düzeylere düşürmek,

- $\quad$ Ekonominin büyüme potansiyelini artırmak,

- $\quad$ Ekonomideki kaynakların daha etkin ve adil dağılımını sağlamaktır. 
Grafik 3.3. 1999-2000 Y lllan Bütçe Dengesi (12 Aylık)

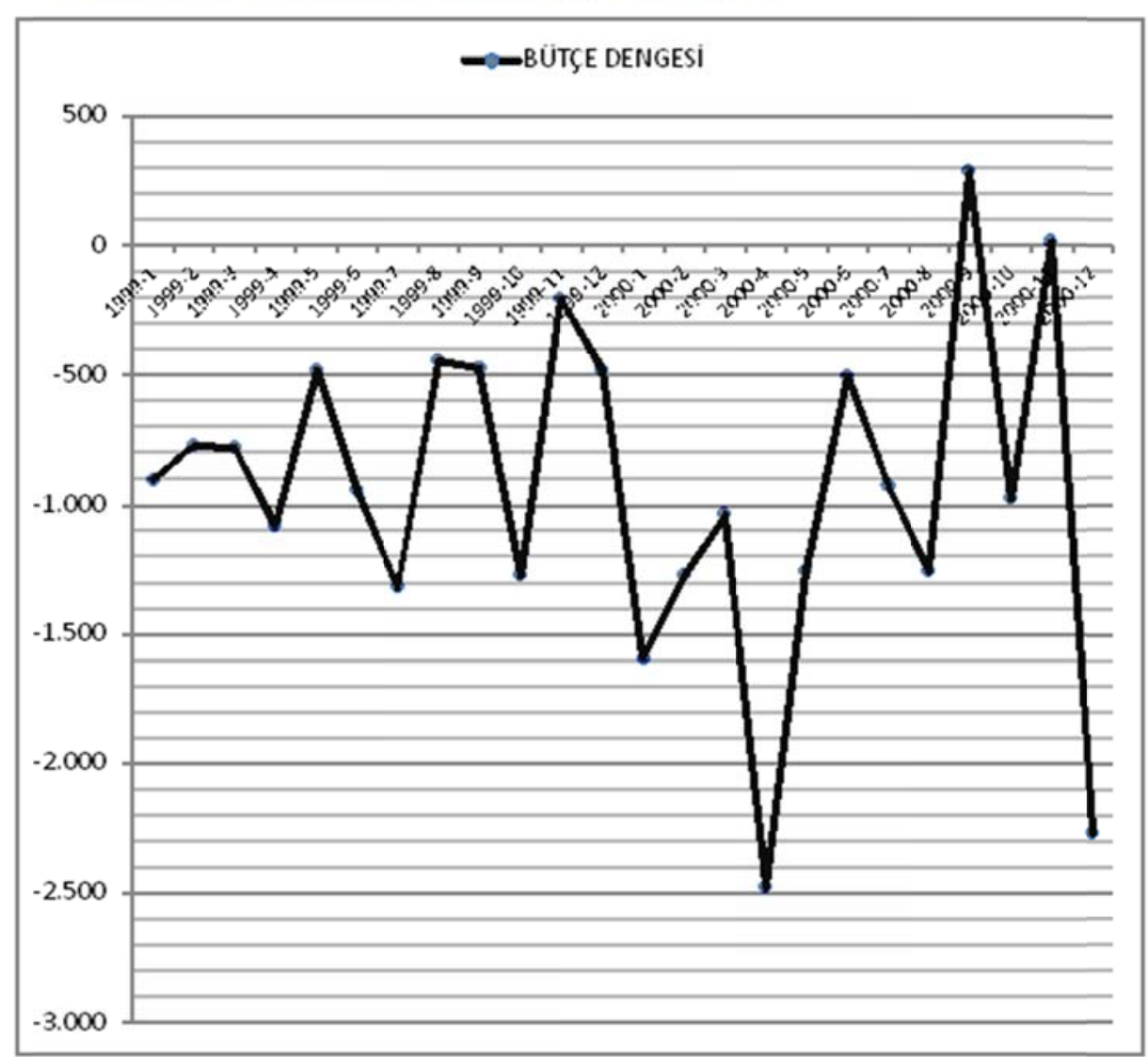

Kaynak: Hazine Müsteșarhğ

Program uygulamaya girdikten sonra, ilk üç ay ekonomide genel bir rahatlama olmuştur. Fakat cari açık hızla büyümüş ve bankalar dışarıdan aşırı şekilde borçlanmıştır (Kumcu, 2009: 181). Grafik 3.3'te görüldüğü gibi ilk üç aydan sonra bütçe gelir-gider dengesi de yüksek oranda açık vermiştir.

\subsection{2. Şubat 2001 Krizi ve Bütçe Açıkları}

Bu dönemde IMF ile yapılan programların çoğunda yardım miktarları sınırlı tutulmuştur. Kredi notunun düşürülmesi dış kaynak bulmada bir diğer sıkıntı olmuştur. 1999 yılında sağ ve sol partilerle oluşturulan koalisyon hükümeti, ekonomide zamanında alınması gereken birçok kararı siyasi çekişmeler yüzünden alamamıştır. IMF programlarının başarısız olmasındaki bir etkende bu tarz koalisyon hükümetleridir. Kaynak ihtiyacının had safhada olduğu bir dönemde Türk Telekom gibi büyük devlet kuruluşlarının özelleştirilmesinin geciktirilmesi bütçe üzerinde ağır bir yük oluşturmuştur (Öniş, 2009: 6). 


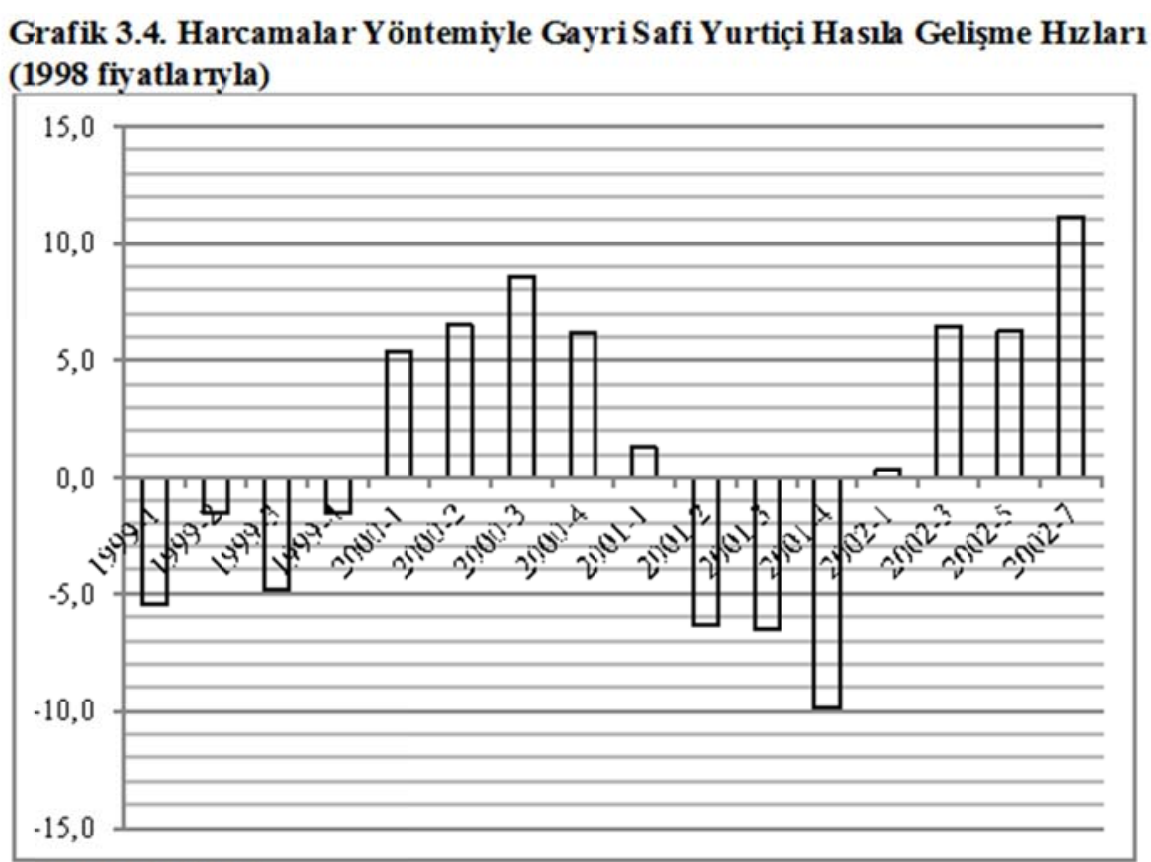

Kaynak: T CMB

Kasım 2000 krizinin ekonomi üzerindeki yıkıcı etkisi giderilmeye çalışılırken 19 Şubat 2001 tarihinde Cumhurbaşkanı ile Başbakan arasında Milli Güvenlik Kurulu'nda yaşanan tartışma spekülatif bir atağa yol açmış ve döviz krizi başlamıştır. 21 Şubatta bankalar arası piyasada gecelik faiz \% 6200'e kadar çıkmış ve ortalama \% 4018 civarında olmuştur. Merkez Bankası döviz rezervleri, 23 Şubatta yaklaşık 5.3 milyar dolar gerileyerek 22.58 milyar dolara düşmüştür. Merkez Bankası 21 Şubat gecesi döviz kurunu dalgalanmaya bırakmış ve 28 Şubata kadar kur artış1 \% 40 olmuştur (Tunalı: 2011: 64).

\subsubsection{Güçlü Ekonomiye Geçiş Programı}

Kasım 2000 ve Şubat 2001 krizleri, istikrar programının güçlü mali uyum önlemleri ile yeniden düzenlenmesine neden olmuştur. Üst üste yaşanan krizler, Türkiye'nin mali dengesini sürekli olarak (yüksek kalitede harcamalarla) güçlendirmesi gerektiğinii, şeffaf bütçeleme sürecini, iyi idare edilen harcama ve gelir idarelerine olan ihtiyacı göstermiştir. Bu amaçla Mayıs 2001'de "Güçlü Ekonomiye Geçiş Programı" ilan edilmiş ve bir dizi yasal düzenlemeler hayata geçirilmiştir. $\mathrm{Bu}$ süreçler makroekonomik isstikrara ve mali sürdürülebilirliğe katkı vererek krizden çıkış sürecini hızlandırmıştır (Karakurt ve Akdemir, 2010: 246).

Programın ilk maddesinde 1990'lı yıllar boyunca yaşanan krizlerde dış etkiler olmakla beraber temel olarak krizlerin nedeni iki ayak üzerine oturtulmuştur. Bunlar;

(i) Sürdürülemez bir iç borç dinamiğinin oluşması, Grafik 3.5' de kriz başladıktan birkaç ay sonra yine iç borç stokundaki hızlı artış rahatlıkla görülebilmektedir.

(ii) Başta kamu bankaları olmak üzere mali sistemdeki sağlıksız yapının ve diğer yapısal sorunların kalıcı bir çözüme kavuşturulamamış olmasıdır (TCMB, GEGP, 2001: 1). 


\section{Grafik 3.5. 1990-2002 Yullani İç Borç Stoku Değișimi}

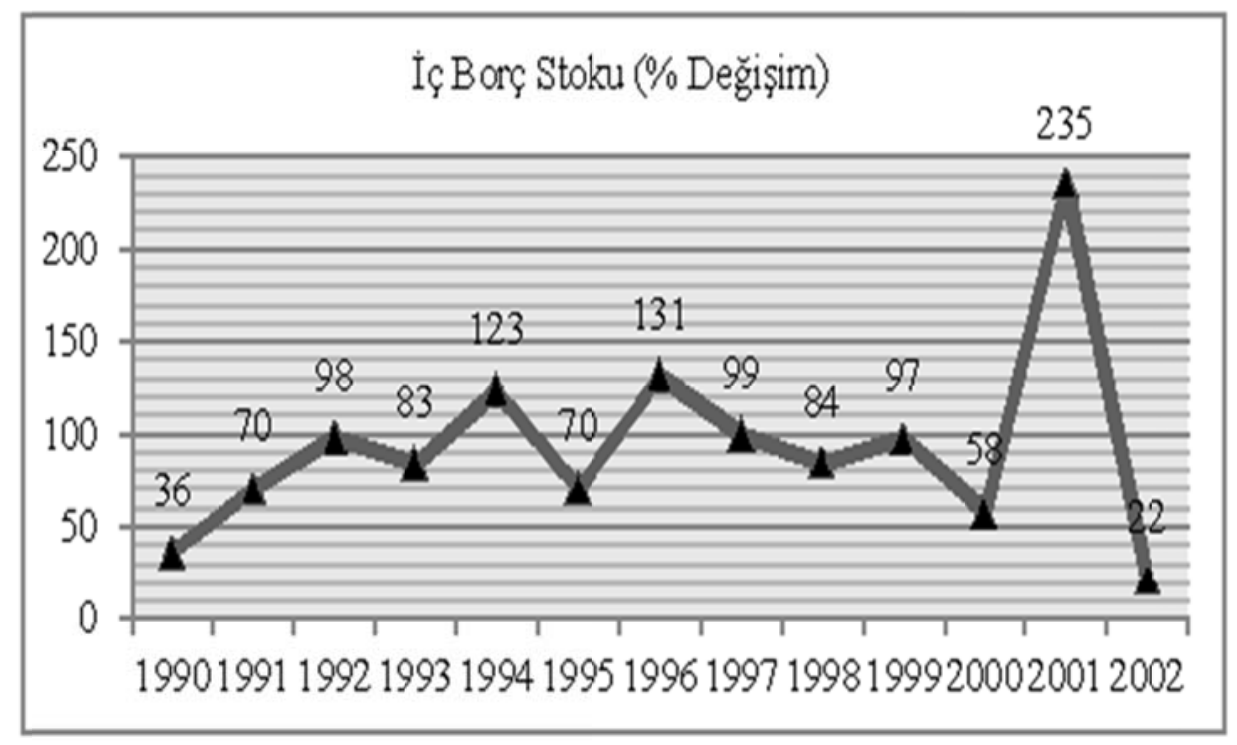

\section{Kaynak: Merkez Bankası}

Grafik 3.6'de görüldüğü gibi 2000 yılının büyük bir bölümünde kamu gelirleri giderleri karşılayamamış ve bütçe açık vermiştir. Kasım ayından sonra alınan tedbirlerle açık azalmaya başlamış ve 2001 yılının ilk aylarına kadar durum böyle devam etmiştir. Şubat krizinin patlamasından sonra Mart ayından itibaren açıklar ciddi şekilde artmıştır.

Genel olarak "Güçlü Ekonomiye Geçiş Programı" (GEGP) kamu maliyesi ve kamu açıklarına yönelik gözlem ve çözüm önerilerini aşağıdaki gibi sıralamak mümkündür (TCMB, GEGP, 2001: 2-6);

- $\quad$ Kamu kesimi toplam borç stokunun (net) GSMH'ya oranı iç borç stokundaki artışın çarpıcı boyutlara ulaşması,

- $\quad$ Yüksek kamu açıklarının yanı sıra 1994 yılından sonra kamu kesiminin net dış borç ödeyici durumunda olması, yeterince derin olmayan yurtiçi mali piyasalar üzerinde baskı oluşturmuş ve reel faiz oranlarının yüksek seviyede kalmasına yol açmıştır. Yükselen reel faizler kamu kesiminin borçlanma ihtiyacını daha da artırmış ve her gün Türkiye'yi daha zor bir duruma götüren bir borç-faiz kısır döngüsünü ortaya çıkarmıştır.

- Kamu gelirlerinin kamu harcamalarını karşılayamamasının bir nedeni olarak, vergi oranlarının yüksek olmasına rağmen vergi tabanının dar olması gösterilmiştir. Bundan dolayı toplam vergi tahsilâtı yetersiz kalmakta ve vergi yükü adaletsiz bir biçimde dağılmaktadır.

- $\quad$ İç borçlanmaların yüksek maliyetle yapılması faiz giderlerini artırmıştır.

- $\quad$ Son yıllarda yüksek reel faizlere de bağlı olarak kamu kesimi borçlanma ihtiyacındaki artış, özel bankaların reel ekonomiye kaynak sağlamaktan uzaklaştırıp kamu açıklarını finanse etmeye yönelmelerine yol açmıştır. 


\section{Grafik 3.6. 2000/2001 Ylllan Aylk Konsolide Bütçe Gerçekleșmeleri(Milyar TL)}

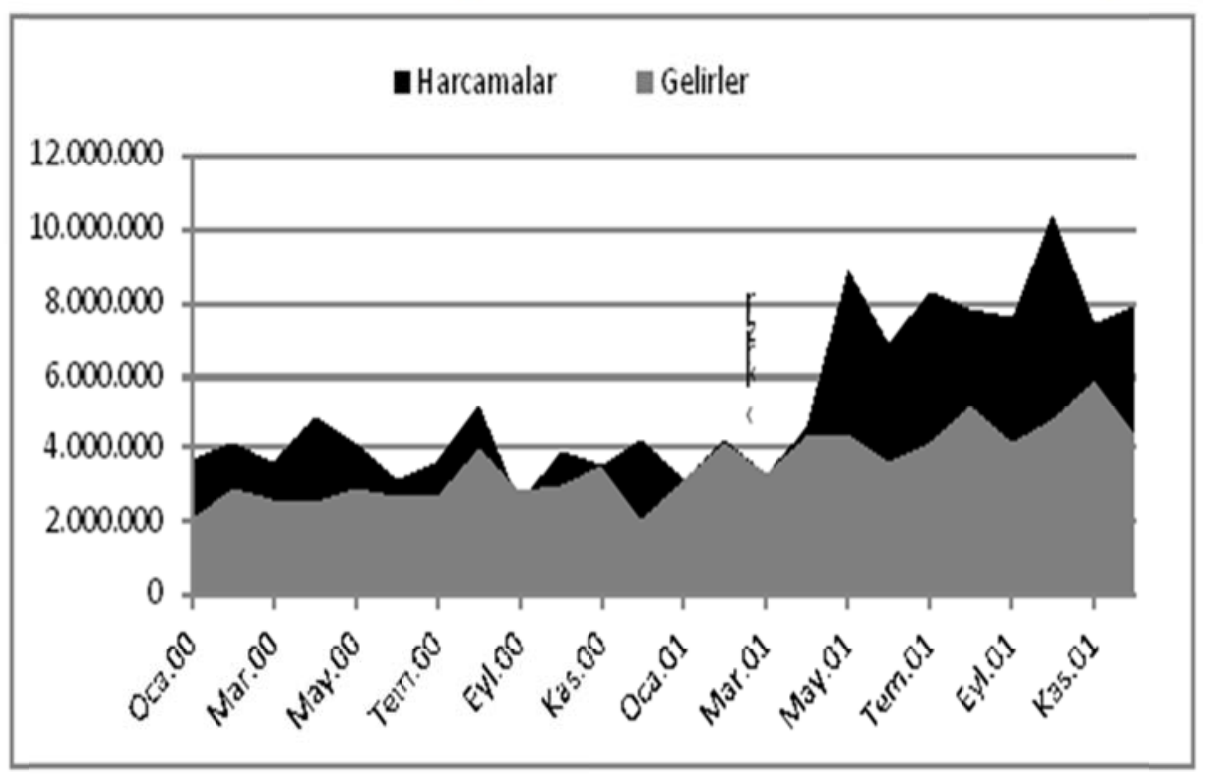

\section{Kaynak: Maliye Bakanhğ}

GEGP'nın temel amacı "kur rejiminin terk edilmesi nedeniyle ortaya çıkan güven bunalımı ve istikrarsızlığı süratle ortadan kaldırmak ve eşanlı olarak bu duruma bir daha geri dönülmeyecek şekilde kamu yönetiminin ve ekonominin yeniden yapılandırılmasına yönelik altyapıyı oluşturmaktır" şeklinde belirtilmiştir (TCMB, GEGP, 2001: 12).Ayrıca programda bütçe açıklarına yönelik olarak "Kamu finansman dengesini bir daha bozulmayacak bir biçimde güçlendirme..." şeklinde hedefler konularak bütçe açıklarının çözümüne yönelik ciddi bir irade ortaya konmuştur.

\subsubsection{Yılı Acil Eylem Planından Günümüze Bütçe Açıkları}

Türkiye 2002 yılına seçim havasında girmiştir. 2002 yılının ikinci yarısından sonra seçim kararı alınınca, her dönemde olduğu gibi artık ekonomik hedeflerden çok siyasi rant ön plana çıkmış ve seçim ekonomisi dönemi başlamıştır. Seçim sonrasında siyasi istikrarın sağlanması beklentileri artırmıştır. 1990'lardan beri krizlerden gözünü açamayan bir ekonomiyi devralan 58. hükümet acil olarak bir dizi önlemler almaya başlamış bunları da "58. Hükümet Acil Eylem Planı (AEP)" şeklinde kamuoyuna duyurmuştur.

3 Kasım 2002 tarihinde yapılan genel seçimler sonucu kurulan 58. Hükümet ile başlayan yeniden yapılanma süreci Türkiye ekonomisi için nispeten olumlu gelişmelerin yaşandığı bir dönem olmuştur. Kamu açıklarını kapatabilmek ve enflasyon oranını aşağı çekebilmek için uygulanan daraltıcı mali önlemler sonucunda bütçe açığı azalmış ve buna bağlı olarak kamu mali dengesinde nispi bir düzelme ortaya çıkmıştır. Ancak bu olumlu gelişmeye rağmen, daraltıcı mali ve parasal tedbirlerin reel ekonomi üzerindeki olumsuz etkilerini ortadan kaldırmaya yönelik düzenlemelerin de acil olarak gerçekleştirilememesi reel ekonomide bazı sektörlerin daralmasına yol açmıştır (Şimşsek: 2007: 64). 
Grafik 3.7. 2000 Ylı Son rası Merkezi Yönetim Bütçe Büyüklükleri (GSYH 'ya Oranlarn)

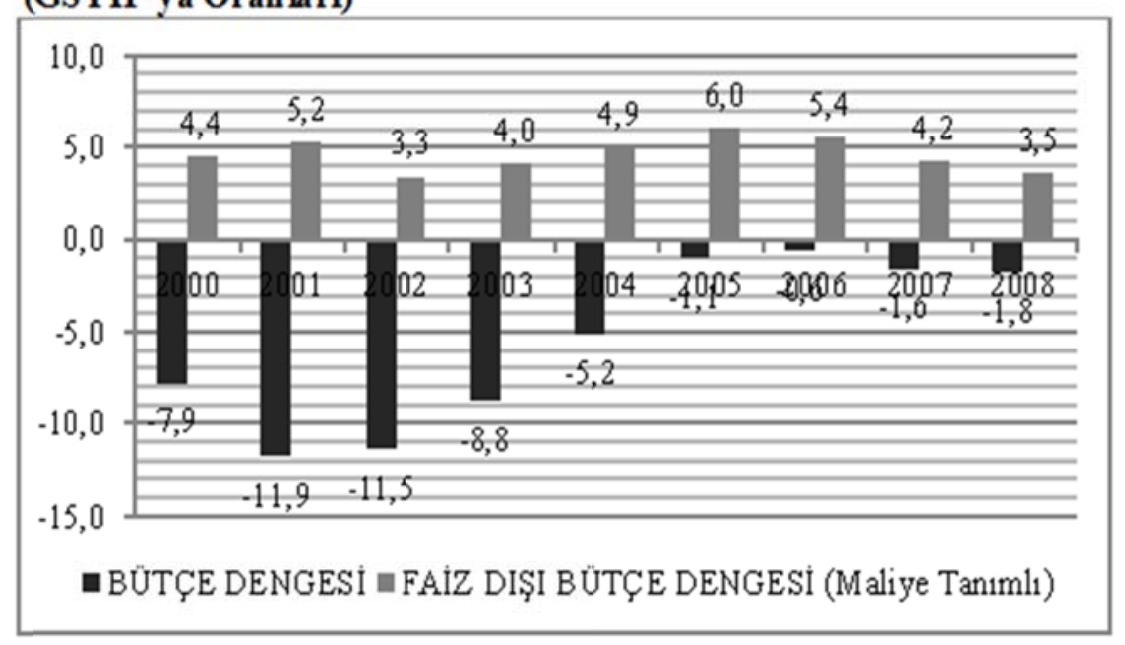

\section{Kaynak: Maliye Bakanlığ}

Türkiye ekonomisinde 58. Hükümetten sonra uygulanan daraltıcı mali önlemler içeren istikrar programının uygulanmasına, özellikle faiz dışı fazla hedefinin tutturulmasına yönelik düzenlemelere 2005 yılından sonra da devam edilmiştir. Dolayısıyla bu sıkı politikalar kamu maliyesinde yaşanan iyileşmenin sürekliliğine hizmet edip, kamu açıklarında belirlenen hedeflere ulaşmayı veya az farkla tutturabilmeyi sağlamıştır (Şimşek, 2007: 64). Grafik 3.7'ye bakıldığında, geçmiş yıllarla karşılaştırıldığında kamu mali dengesinin istikrar kazandığı ve bu istikrarın devam ettiğini görülmektedir. 2000 yılından 2004'e kadar \% 5 oranının altına düşmeyen bütçe dengesi 2005 yılından itibaren \% 2 oranını geçmemiştir.

Tablo 3.2. 2001-2008 A rası Temel Ekonomik Büyüklükler

\begin{tabular}{|c|c|c|c|c|c|c|c|c|}
\hline Bütçe Gideri & $\begin{array}{l}2001 \\
86.972\end{array}$ & $\begin{array}{l}2002 \\
119.604\end{array}$ & $\begin{array}{l}2003 \\
141.248\end{array}$ & $\begin{array}{l}2004 \\
152.093\end{array}$ & $\begin{array}{l}2005 \\
159.687\end{array}$ & $\begin{array}{l}2006 \\
178.126\end{array}$ & $\begin{array}{l}2007 \\
204.068\end{array}$ & $\begin{array}{l}2008 \\
227.031\end{array}$ \\
\hline Bütçe Geliri & 58.416 & 79.420 & 101.040 & 122.964 & 152.784 & 173.483 & 190.360 & 209.598 \\
\hline Bütçe Açığı & 28.556 & 40.184 & 40.208 & 29.128 & 6.903 & 4.643 & 13.708 & 17.432 \\
\hline $\begin{array}{l}\text { GSYH Büyüme } \\
(\%)\end{array}$ & $-4,7$ & 6,8 & $-5,7$ & 6,2 & 5,3 & 9,4 & 8,4 & 6,9 \\
\hline ÜFE Yillk Ort. & 61,6 & 50,1 & 25,6 & 11,1 & 5,9 & 9,3 & 6,3 & 12,7 \\
\hline $\begin{array}{l}\text { TÜFE } \\
\text { Ort. }\end{array}$ & 54,4 & 45,0 & 25,3 & 10,6 & 8,2 & 9,6 & 8,8 & 10,4 \\
\hline $\begin{array}{l}\text { İç } \\
\text { Borçlar/GSYH }\end{array}$ & 50,9 & 42,8 & 42,7 & 40,2 & 37,7 & 33,2 & 30,3 & 28,9 \\
\hline $\begin{array}{l}\text { Diș } \\
\text { Borçlar/GSYH }\end{array}$ & 23,2 & 26,5 & 19,4 & 16,5 & 13,4 & 12,3 & 9,3 & 11,1 \\
\hline $\begin{array}{ll}\text { Ort. } & \text { Dolar } \\
\text { Kuru } & \end{array}$ & 1,225 & 1,506 & 1,493 & 1,422 & 1,341 & 1,431 & 1,302 & 1,293 \\
\hline $\begin{array}{l}\text { İșsizlik } \\
(\%)\end{array}$ & 8,4 & 10,3 & 10,5 & 10,8 & 10,6 & 10,2 & 10,3 & 11,0 \\
\hline
\end{tabular}

Kaynak: Maliye Bakan hğı, Ka Ikmma Bakanlı̆̆, TCMB

2007 yılı ortalarında yine tek başına iktidara gelen hükümet, daraltıcı istikrar politikalarına ve mali disiplin uygulamalarına devam etmiştir (Akiş, 2011: 126). Alınan kararların çoğunun 
kararlılıkla uygulanması Tablo 3.2'de görüldüğü gibi temel ekonomik büyüklükler üzerinde olumlu etki meydana getirmiştir. Ancak uygulanan daraltıcı politikalar sonucunda işsizlik oranı belli bir seviyenin altına düşürülememiştir. 2007 yılının ikinci yarısında ABD'de konut kredilerinin geri ödenmesi hususunda yaşanan sıkıntılar yüzünden finansal piyasalarda meydana gelen dalgalanmalar, 2008 yılı eylül ayından itibaren etkisini artırarak küresel bir boyuta ulaşmıştır. ABD ve Avrupa' da birçok banka iflas etmiş ve iflasların önüne geçebilmek için kamu müdahaleleri gerçekleşmiştir. Dünyaya yayılan kriz birçok ülkede durgunluklara ve işsizliklere neden olmuştur. Birçok ülke ile ticari ve finansal anlamda ilişkileri bulunan Türkiye ekonomisi de çeşitli alanlarda bu krizden olumsuz yönde etkilenmiştir (Akiş, 2011: 127).

Küresel krizin Türkiye ekonomisi üzerindeki olumsuz etkilerini sınırlandırmak amaciyla 2008 yılı ortalarından itibaren gerek kamu harcamaları gerekse kamu gelirleri bakımından bir dizi tedbirler alınmıştır. Ayrıca Merkez Bankası, BDDK ve SPK'nın aldığı tedbirlerin yanı sıra, bütçe dengesi üzerinde doğrudan veya hemen etkisi olmayan kredi ve garanti hacmini artırıcı önlemler de hayata geçirilmiştir. Alınan bu önlemlerle, mal piyasalarındaki işlem miktarını ve dolayısıyla mal ve para akışını artırarak istihdam ve üretim seviyesinin korunması amaçlanmıştır. Bu şekilde hem ekonomiye nispeten bir canlılık kazandırabilmiş hem de bütçe dengesini büyük oranda bozacak uygulamaların önüne geçilmiştir (OVP, 2009: 4).

\subsubsection{Sonrası Dönemin AB Ülkeleri Bazında Karşılaştırılması}

Tablo 3.3. Avrupa Birliği Üye Devletlerive Türkiye Bütçe Açlkları/ GSYH Oranları

\begin{tabular}{|c|c|c|c|c|c|c|c|c|c|c|c|c|}
\hline & 2000 & 2001 & 2002 & 2003 & 2004 & 2005 & 2006 & 2007 & 2008 & 2009 & 2010 & 2011 \\
\hline $\begin{array}{c}\text { Avro Bölgesi (27 } \\
\text { Ülke) }\end{array}$ & $\mathrm{kn}$ & $-1,5$ & $-2,6$ & $-3,2$ & $-2,9$ & $-2,5$ & $-1,5$ & $-0,9$ & $-2,4$ & $-6,9$ & $-6,5$ & $-4,4$ \\
\hline Bulgaristan &, 5 & 1,1 & $-1,2$ & $-0,4$ & 1,9 & 1 & 1,9 & 1,2 & 1,7 & $-4,3$ & $-3,1$ & -2 \\
\hline Ir & 4,7 & 0,9 & $-0,4$ & 0,4 & 1,4 & 1,7 & 2,9 & 0,1 & $-7,4$ & 13,9 & 30,9 & 13,4 \\
\hline Yu & $-3,7$ & $-4,5$ & $-4,8$ & $-5,6$ & $-7,5$ & $-5,2$ & $-5,7$ & $-6,5$ & $-9,8$ & 15,6 & 10,7 & $-9,4$ \\
\hline İngilt & 3,6 & 0,5 & $-2,1$ & $-3,4$ & $-3,5$ & $-3,4$ & $-2,7$ & $-2,8$ & $-5,1$ & 11,5 & 10,2 & $-7,8$ \\
\hline Portekiz & $-3,3$ & $-4,8$ & $-3,4$ & $-3,7$ & -4 & $-6,5$ & $-4,6$ & $-3,1$ & $-3,6$ & 10,2 & $-9,8$ & $-4,4$ \\
\hline İspanya & $-0,9$ & $-0,5$ & $-0,2$ & $-0,3$ & $-0,1$ & 1,3 & 2,4 & 1,9 & $-4,5$ & 11,2 & $-9,7$ & $-9,4$ \\
\hline$T \ddot{U} R K \dot{I} Y E$ & $-6,8$ & $23, \overline{9}$ & 10,2 & -9 & $-4,4$ & $-1,2$ & 0,8 & $-1,5$ & $-2,8$ & -7 & $-2,6$ & $-1,4$ \\
\hline
\end{tabular}

Kaynak: European Community Statistical Office ;Eurostat Verileri (Avrupa Birliği, Avrupa İstatistik Ofisi)

Türkiye'nin 2000-2011 dönemine dair uygulanan maliye politikalarına bakıldığında 2001 sonrası atlatılan ağır kriz ortamından Türkiye hızla çıkmış ve uygulanan politikalar ekonomik veriler üzerinde pozitif etki meydana getirmiştir. Bu durumu bütçe dengesi üzerinde de görülebilmektedir (Sağbaş, 2012: 95). Avrupa Birliği'nin 27 ülke ortallaması ve özellikle birkaç üye devletin 2000-2011 yıllarına dair verileri incelendiğinde 2007 yılı sonrası ağırlaşan krizin bütçe üzerindeki etkisi AB'ye kıyasla Türkiye'de daha rahat atlatılmıştır. 
Tablo 3.3'te görüldüğü gibi krizin başlangıcı olarak kabul edilen 2007 yılında Avrupa Birliği bütçe açığ 1 ortalamas $-0,9$ iken Türkiye'de bu oran -1,5 olarak geçekleşmiştir. 2007 y1lından sonrada açık armış ve bazı üye devletlerde -10 ile -30 arasında değișen oranlarda büyümüştür

\section{Grafik 3.8. 2007 Ylh Sonrası Avrupa Birliği ve Türkiye Bütçe Açıklarnnı GSYH'ya Oranlan}

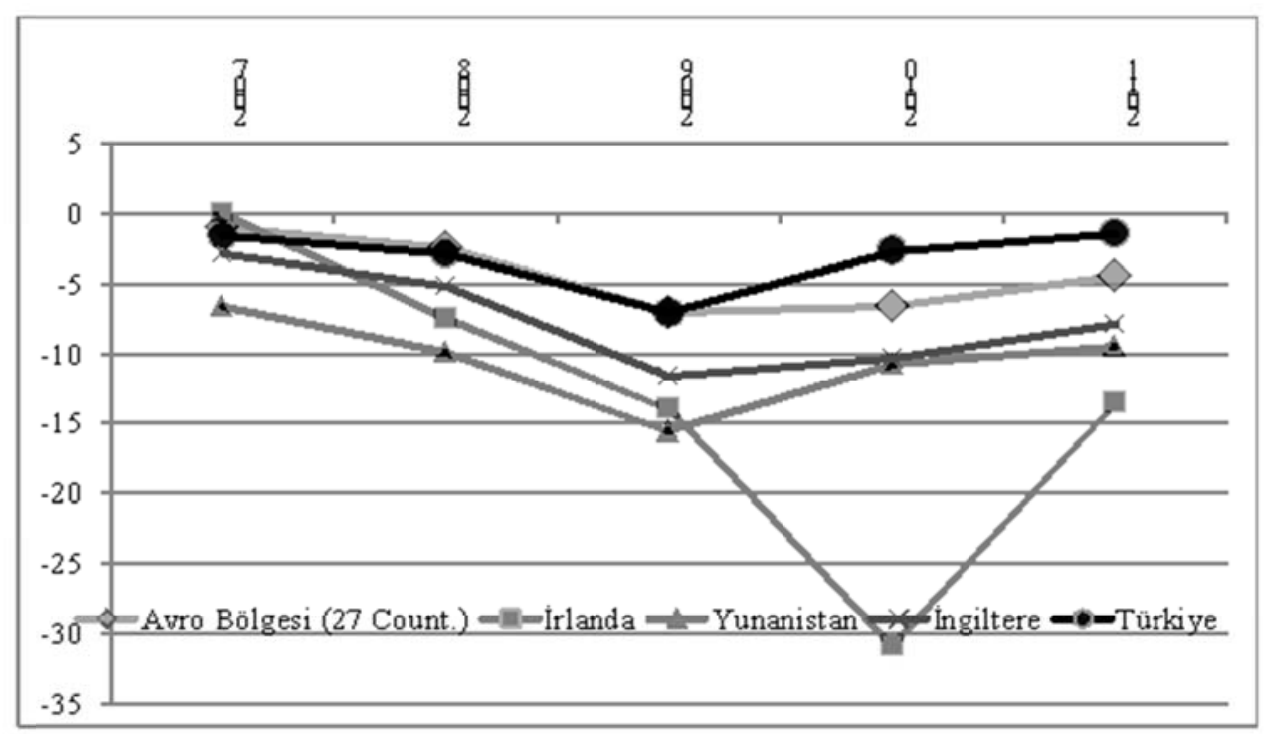

Kaynak: European Community Statistical Office ;Eurostat V erileri (AB Avrupa İstatistik Ofisi)

Avrupa Topluluğunu Kuran Antlaşmanın 121. maddesinde öngörülen yakınlaşma kriterlerine ilişkin protokolün 2. maddesinde 'Üye ülkelerin kamu açıklarının GSYİH'larına oranı \%3'ü geçmemelidir"4 ifadesiyle bütçe açıkları noktasında belli bir oranın geçilmemesini öngörmüştür. Ancak grafik 3.8 incelendiğinde AB'nin bu kriterden çok uzaklaştığ 1 görülmektedir.

\footnotetext{
${ }^{4}$ Eurostat: Government Budgetary Position

(Erişim: http://epp.eurostat.ec.europa.eu/statistics_explained/index.php/Glossary:Maastricht_criteria)
} 
Tablo 3.4. 2007 Sonrası AB ve Türkiye'de Kamu Borç Stokunun GSYH'ya Oranlan

\begin{tabular}{|c|c|c|c|c|c|}
\hline & 2007 & 2008 & 2009 & 2010 & 2011 \\
\hline $\begin{array}{l}\text { Avrupa Bölgesi(27 } \\
\text { Ülke) }\end{array}$ & 59.0 & 62.2 & 74.6 & 80.0 & 82.5 \\
\hline Almanya & 65.2 & 66.8 & 74.5 & 82.5 & 80.5 \\
\hline Ílanda & 24,6 & 44.5 & 64.9 & 92.2 & 106.4 \\
\hline Yunanistan & 107.4 & 112.9 & 129.7 & 148.3 & 170.6 \\
\hline İtalya & 103.3 & 106.1 & 116.4 & 119.2 & 120.7 \\
\hline Belçika & 84.0 & 89.2 & 95.7 & 95.5 & 97.8 \\
\hline Ingiltere & 44.2 & 52.3 & 67.8 & 79.4 & 85.0 \\
\hline$T U ̈ R K \dot{I} Y E$ & 39.9 & 40.0 & 46.1 & 42.4 & 39.2 \\
\hline
\end{tabular}

Kaynak: European Community Statistical Office ;Eurostat Verileri (AB Avrupa İstatistik Ofisi)

Kamu borç yönetimine ilişkin Maastricht Kriteri kamu borç stokunun GSYH'ya oranının \% 60’1 geçmemesini öngörmektedir. Türkiye 2004 yılından bu yana bu oranı yakalamıştır. Tablo 3.4.' ve Grafik 3.9'a baktığımızda 2007 yılından sonra Avrupa Birliği 27 üye devletin genel ortalaması ve birçok ülkenin kendi ortalamaları bu oranı sağlamak bir tarafa giderek bu orandan uzaklaşmıştır. 2011 yılı itibariyle kamu borç stokunun GSYH' ya oranı ortalama olarak AB (27 ülke)'de \% 82, Almanya'da \% 80, İrlanda'da \% 106, Yunanistan'da \% 170, İtalya'da \% 120, Portekiz'de \% 108, İzlanda'da \% 101, Macaristan'da \% 81 olarak gerçekleşmiştir. Eurostat' dan alınan verilere göre 27 üye devletten 1.4'ünün kamu borç stoku/GSYH oranı Maastricht Kriterinin üzerindedir (Sağbaş, 2012: 95).

Grafik 3.9. 2007 Sonrası A B Tanımlı Kamu Borç Stokunun GSMH'ya Oranı

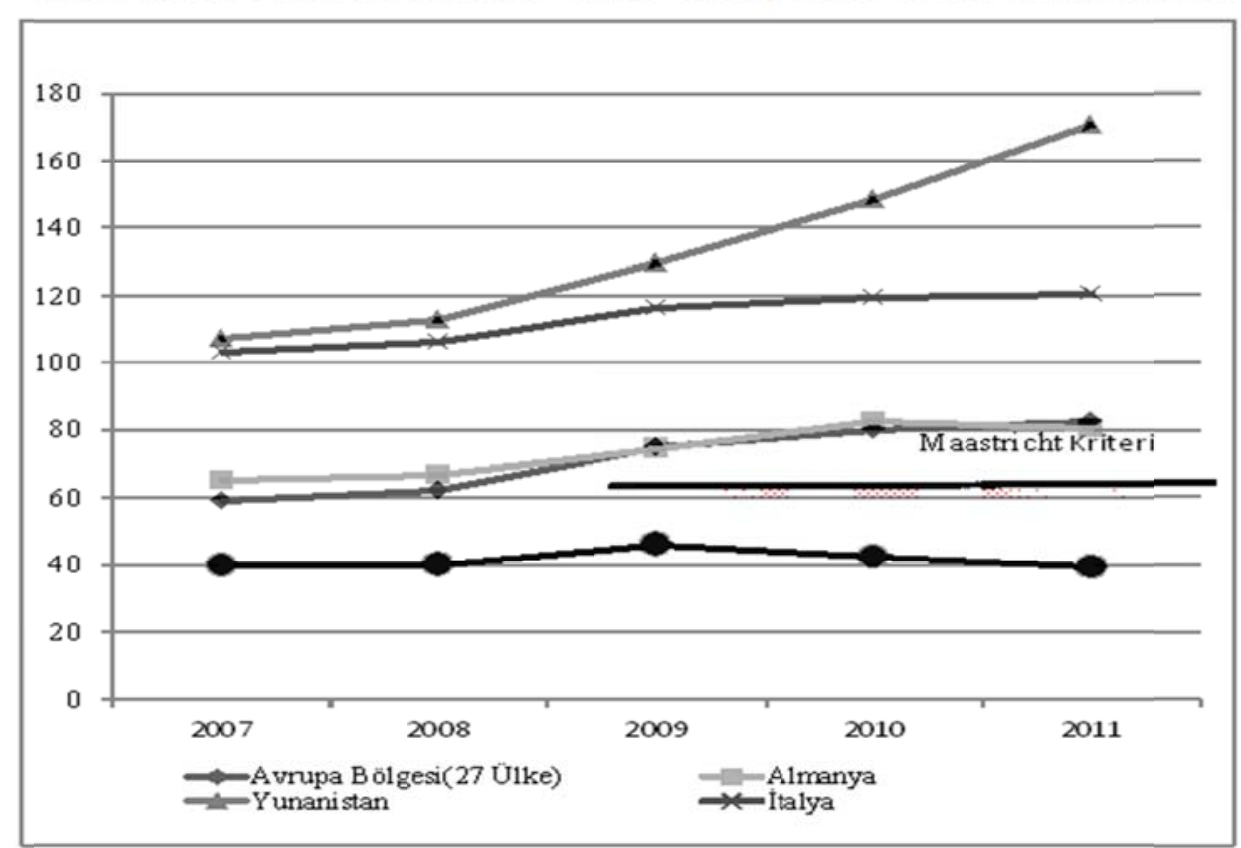

Kayn ak: European Community Statistical Office; Eurostat Verileri (AB A vrupa İsta tistik Ofisi) 


\subsubsection{Günümüzdeki Durum}

Küresel krizin dünya ekonomisi üzerindeki olumsuz etkileri alınan önlemlere rağmen devam etmekte ve ülke ekonomilerindeki yavaşlama eğilimi sürmektedir. Küresel ekonominin durağanlaşması ve zayıflamasının bir nedeni özellikle Avro Bölgesinde yaşanan sorunların ticaret ve güven kanallarıyla diğer bölgelere olumsuz şekilde yansımasıdır. Avro Bölgesinde yaşanan ekonomik ve siyasi gelişmeler küresel görünüm üzerinde belirleyici olmaya devam etmektedir. Genel olarak Avro bölgesinin temel problemlerinden biri bütçe açıklarının kontrol edilemez boyutlara ulaşmasıdır. Kamu gelir ve giderleri arasındalki bu dengesizlik ekonomideki birçok alana da olumsuz şekilde yansımaktadır (OVP, 2012: 1).

Türkiye 2002 yılında yaşadığı büyük ekonomik krizden sonra ekonomide yakın tarihte yakalanamayan rakamlara ulaşıp büyük bir başarı sağlamıştır. Büyüme rakamları, enflasyon oranı, bütçe açıkları gibi çok önemli konularda bir disiplin oluşturup istikrarı yakalayabilmiştir. Ekonominin bu noktaya ulaşmasının temelinde, siyasi istikrarla beraber yakalanan ekonomik istikrar, dış ilişkilerde yaşanan iyileşme süreci ve çok önemli olup yıllarca ihmal edilen bütçe açıklarının ve kamu mali disiplininin sağlanmış olmasıdır (Acar, 2009: 87-88).

\section{Grafik 3.10. 2009 Sonrası 4 Çeyrek Dönemlik GSYH Büyüme Hzlan}

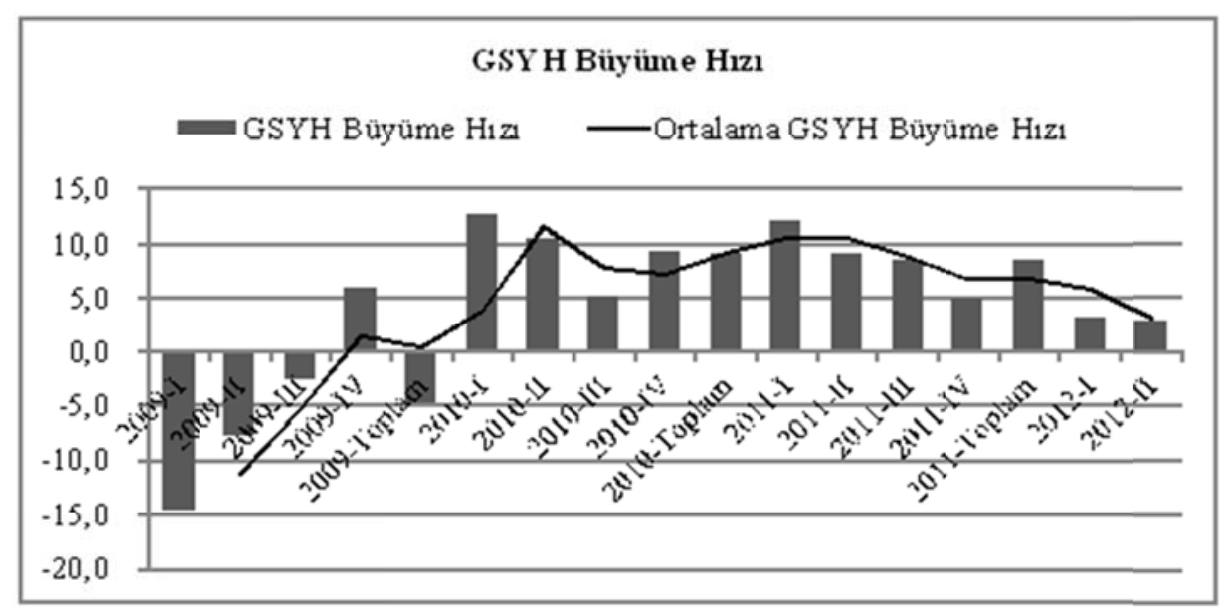

Kaynak: TüİK

Grafik 3.10'dan görüleceği gibi Türkiye 2011 yılında kaydettiği \% 8,5 oranındaki GSYH büyümesiyle, dünyada büyüme hızı en yüksek olan ülkeler arasında yer alımıştır. 2011 yılında büyüme esas olarak özel tüketim ve sabit sermaye yatırımları kaynaklı olmuştur. Sürdürülebilir bir büyüme temel hedefi çerçevesinde; küresel ölçekteki belirsizlikler ve cari işlemler açığındaki artış karşısında alınan önlemler sonucunda, ekonomik faaliyetler özellikle y1lın son çeyreğinden itibaren yavaşlama eğilimine girmiştir. Söz konusu yavaşlama 2012 yılının ilk yarısında da devam etmiştir. Son bir yılda net mal ve hizmet ihracatının büyümeye katkısının giderek artması sonucunda iç talep yavaşlamasının büyüme üzerindeki olumsuz etkisi sınırlı kalmıştır (OVP, 2012: 31). 
Grafik 3.11. Kamu Kesimi Borçlanma Gereğinin GSYH' ya Oranı

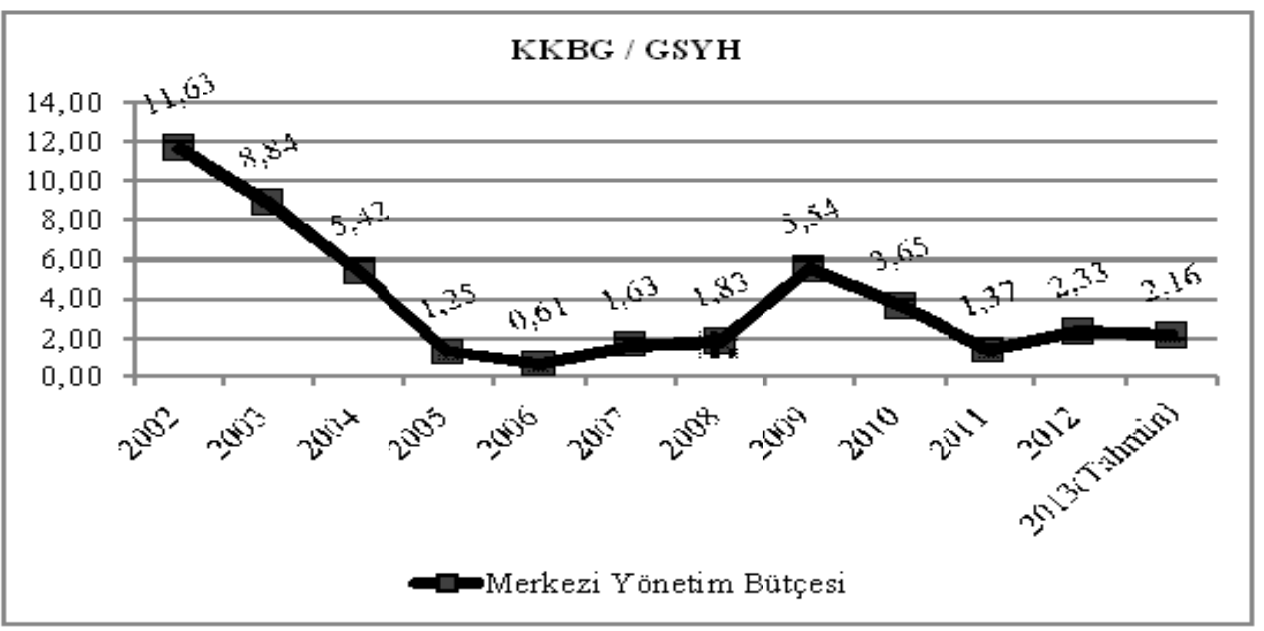

Kaynak: Kalkmma Bakanlı̆̆ı

Grafik 3.11'de Kamu Kesimi Borçlanma Gereğinin GSYH'ya oranına bakıldığında 2002 yılına kıyasla pozitif olarak küçüldüğü görülmektedir. 2006 yılında 0,6 gibi çok düşük oranlara inmiştir. Ancak 2007 yılında başlayan küresel ekonomik kriz ve 2008 yılında iktidar partisine açılan kapatma davasının ekonomideki güven ortamını zedeleyip, tedirgin bir havaya sebep olması KKBG rakamlarına da yansımıştır. 2008 yılında 1,83'e düşen KKBG, 2009 y1lında 5,54 olarak gerçekleşmiştir. Son y1llarda tekrar yakalanan istikrar ortamı ve mali disiplinin kararlılıkla uygulanmasıyla bu oran tekrar \% 2 seviyelerine düşmüştür.

Genel olarak 2001 Krizinden sonra faiz ödemelerinin GSMH içindeki payı hızla düşmüştür. Bütçe dengesi rakamlarında da aynı iyileşme görülmekte, 2008 yılı sonrası dönemde grafik 3.12'dende takip edilebileceği gibi nispeten bütçe açıklarının arttığ 1 ancak 2010 yılından itibaren tekrar toparlanma sürecine girildiği görülebilmektedir.

Grafik 3.12. 2000-2012 Yllarn Arası Bütçe Den geleri ve Faiz Ödemelerinin GSMH'ya Oranlan

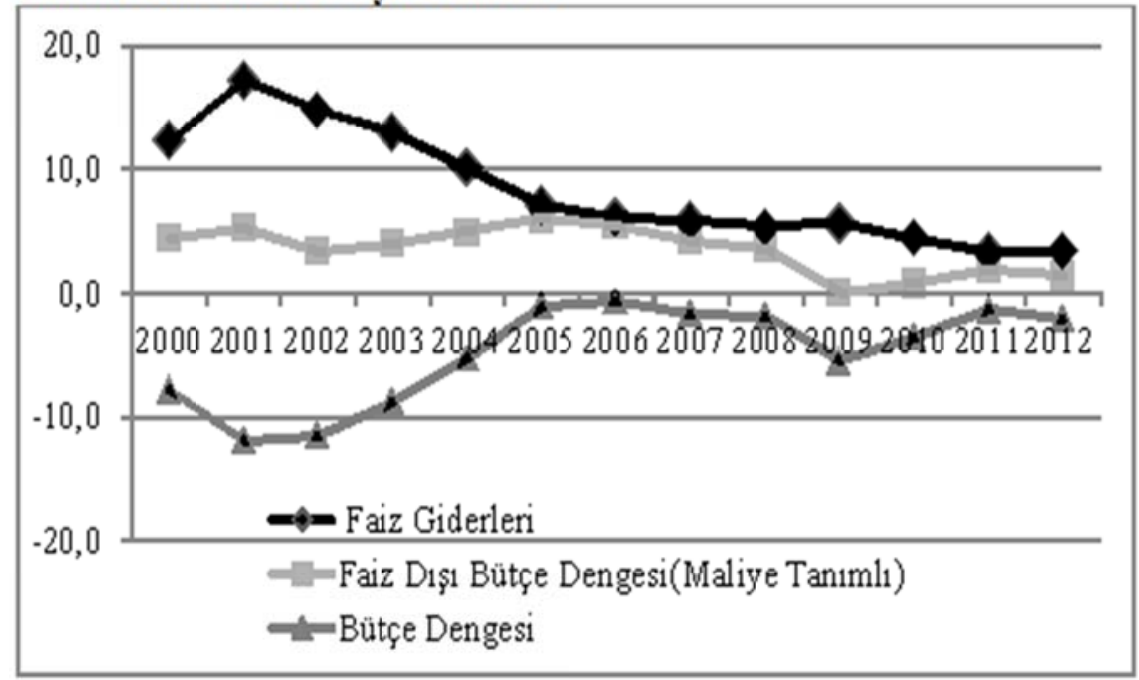

Kaynak: Maliye Bakanlığ 


\section{Sonuç}

Devletin gelir ve giderleri arasındaki negatif fark olan bütçe açıkları konusunda, iktisatçılar arasında tam bir görüş birliği söz konusu değildir. Bütçe açıklarının çok farklı nedenleri olabilir. Türkiye'nin yıllarca sağlayamadığı ekonomik ve siyasi istikrarın olmayışı, yükselen enflasyon oranları, iç ve dış borçlanmalar, hükümetlerin merkez bankasından karşılıksız borçlanmaları ve kamu gelirlerinin yetersiz oluşu gibi sorunlar uzun yıllar çözülememiştir. Ekonominin bu kronik sorunları Türkiye'ye pahalıya mal olup, sık sık ekonomik krizlerin çıkmasına neden olmuştur. Kriz dönemlerinde bütçe açıkları hızla artarken, kriz sonrasında ekonominin bozulan dengesini sağlamaktaki başarısızlıklar açıkların kronikleşmesine neden olmuştur.

Bütçe açıklarının makroekonomik etkileri de çok çeşitlidir. Milli gelirle beraber kişi başına düşen milli geliri de olumsuz etkilemektedir. Açıkların arttığı dönemlerde enflasyon oranının arttığı, açıkların azaldığı dönemlerde fiyat artışlarının artış hızının düştüğü gözlemlenmiştir. Enflasyon ve bütçe açıkları arasında ayrıca bir kısır döngü mevcuttur. Enflasyon artışı bütçe açıklarını artırmakta, bütçe açıklarını kapatmak için yapılan parasal müdahaleler enflasyonu artırmaktadır. Çalışmamızın temel hedefini teşkil eden kriz dönemlerinde bütçe açıklarının kapatılmasına yönelik tedbirlerin etkinliği ise krizden krize farklılık göstermiştir.

5 Nisan 1994 kararlarının alındığ 1 dönem ve sonrasına bakıldığında, istikrar politikalarının genel olarak başarısız olduğu sonucuna varılmıştır. Bunun birçok nedeni olmakla beraber en çok öne çıkanlar; siyasi ve ekonomik istikrarsızlıklar, yüksek enflasyon, mali disiplin anlayışının tam oturmamış olması, kararların daha çok cari olarak bütçenin gelir kısmını rakamsal olarak artırıp gider tarafını azaltmak yönünde olması yapısal sorunların çözümüne yönelik olmaması, özelleştirme uygulamalarında geç kalınması gibi sebepler gösterilebilir. Gerek tedbirlerin uzun vadeli amaçlara hizmet etmemesi, gerekse siyasi istikrarsılıklar sonucu, açıklar giderek artan boyutlarda devam etmiştir. Ekonomik ve siyasi istikrarsılılılar Türkiye'yi 2000 ve 2001 yıllarında yaşanan krizlere sürüklemiştir.

2000 yılında da uygulamaya konulmaya çalışılan programlar kâğıt üzerinde bir temenni olmaktan öteye geçememiştir. Sonunda 2001 y1lının Şubat ayında Cumhuriyet tarihinin en büyük krizlerinden biri yaşanmıştır. Kamu açıkları rekor seviyelere ulaşmıştır. Mayıs 2001'de "Güçlü Ekonomiye Geçiş Programı (GEGP)" adı altında bir dizi önlemler alınmıştır. GEGP, belki de o güne kadarki istikrar tedbirlerinin en gerçekçi olanıdır. Ekonominin ve özellikle kamu açıklarının yapısal nedenleri çok iyi analiz edilmiş ve uzun vadeli çözümler önerilmiştir. Hemen hızlı bir şekilde o yıl içinde vergi gelirlerini arttırmak, yüksek oranlı zamlar yapmak, harcamaları kısmak gibi geçici çözümler yerine, kamu harcamalarını gereksiz artıran ve kamu gelirlerinin yetersiz oluşuna sebep olan faktörlerin ortadan kaldırılması gerektiğinin önemi vurgulanmıştır. Ancak kararlar her ne kadar çok gerçekçi ve başarılı da olsa siyasi çalkantılar ve halk desteğini kaybetmiş bir meclisle bu kararları uygulamak mümkün olmamıştır. 2000 yılı Enflasyonu Düşürme Programı ve 2001 yılı GEGP'na bakıldığında; GEGP'nın daha gerçekçi çözümler içermesine rağmen iki programında başarısız olduğu gözlemlenmiştir. Bu yıllarda koalisyon hükümetlerindeki iç çekişmeler, yüksek enflasyon oranı, istikrar paketindeki önlemlerin uygulanamaması, iç ve dış borç anapara ve faiz ödemelerinin bütçe üzerindeki ağır yük oluşturması gibi nedenler bu programların başarısız olmasındaki sebepler arasındadır. 
2002 yılında uygulamaya konan "Acil Eylem Planı" ve daha sonra zaman zaman alınan tedbirlerin aslında "Güçlü Ekonomiye Geçiş Programı"nın kısmi olarak devamı niteliğinde olduğu görülmektedir. Çünkü GEGP'ında gerçekten bütçe açıklarının kapatılması için geçici çözümler yerine, kalıcı ve uzun vadeli uygulamalara yer verilmiştir. O dönem uygulama imkânı bulunmayan tedbirler, 2002 sonrası sağlanan siyasi istikrarla uygulanabilmiştir. Acil Eylem Planının uygulanması ile bütçe açıklarında hızlı bir iyileşme görülmesi bu istikrar paketinin açıkların kapatılmasında başarılı olduğunun bir göstergesidir.

2007-2008 yıllarında başlayan küresel ekonomik kriz, özellikle Avrupa" da bazı devletlerin kamu açıklarını olağanüstü boyutlara ulaştırmış hatta bazı devletler iflasın eşiğine gelmiştir. Türkiye'de bütçe her ne kadar bu krizden doğal olarak etkilense de krizin kamu açıkları üzerindeki etkisi sınırlı olmuştur. $27 \mathrm{AB}$ üyesinden 14 devletin kamu borç. stokları Maastricht Kriterlerinin üzerindeyken, Türkiye bu kriterleri bütçe açıkları ve kamu borç stoku gibi noktalardan çok rahat sağlamaktadır. Böyle bir başarının sağlanmasında son yıllarda özelleştirme uygulamalarının hızlandırılarak hantal yapıda olup sürekli bütçe üzerinde ağır yük oluşturan kurumların devlet bünyesinden çıkarılması, kamu mali dengesi için mali disipline son derece önem verilmesi ve çok yerinde olan daraltıcı maliye politikaları uygulanmasının payı büyüktür.

2007 ve 2008 yıllarında bütçe açıklarının tekrar artmış olması göstermektedir ki; siyasi istikrarsızlıklardan dolayı güven ortamının bozulması da kamu bütçe açıklarını olumsuz etkilemektedir. 2008 yılında iktidar partisine açılan kapatma davası ülkede genel bir tedirginlik havası oluşturmuştur. 14 Mayıs 2008'de açılan dava, 30 Temmuz da sonuçlanarak parti kapatılmamıştır, ancak hazine yardımlarının kesilmesi noktasında söz konusu partiye bir ceza verilmiştir. Bu dönemin bütçe açıkları üzerindeki etkileri, çalışmamızın son bölümdeki veri ve grafiklerde açık bir şekilde görülebilmektedir.

Türkiye ekonomisinde, bütçe açıkları noktasında elde edilen başarıların arkasında; siyasi istikrarla beraber, ekonominin yapısal sorunlarını çözmeye yönelik gerekli olan tedbirlerin alınması ile mali disiplin hususunda son derece hassas olan bir ekonomi yönetiminin olduğu söylenebilir. Bu başarı unsurlarına özellikle de mali disipline uygun olarak ekonominin yönetiminde istikrar olmasının, Türkiye' de bütçe açıklarının istenilen düzeylerde kalmasında büyük bir öneme sahip olduğunu göstermiştir. 


\section{REFERENCES}

- Acar M., Güncel İktisadi Tartışmalar, Orion Kitabevi, Ankara 2009.

- Akiş E., Soyyiğit K.S., Çağlar Ü, “Türkiye'de 2000 Sonrası Uygulanan Maliye Politikaları",(Ed: Y. Alpaydın, H. tunalı), 2000 Sonrası Türkiye İktisadının Değişimi, İstanbul Ticaret Odas1 Yayınlar1 Yayın No:2011-31, İstanbul 2011.

- Altuğ F., "Konsolide Bütçe Açıkları", Kamu Kesimi Finansman Açıkları, X.Türkiye Maliye Sempozyumu, İstanbul 1994.

- Aslan M., Bilge S., “Türkiye'de 1950-2006 Döneminde Bütçe Gellir -Gider Yönetimi Üzerine Ampirik Bir Çalışma: Tek Parti ve Koalisyon Hükümetlerinin Karşılaştırması”, Süleyman Demirel Üniversitesi İİBF Dergisi, , C:14 S:3, Y11 2009.

- Ataç B., Bütçe Açı̆̆ı ve Devlet Borçları, (Ed: Varcan N., Çakır T.), Kamu Maliyesi, Anadolu Üniversitesi Yayın No:1682, Eskişehir 2009.

- Aydin Z., The Political Economy of Turkey, Pluto Press, London 2005.

- Aytaç D., "Maastricht Antlaşması Yakınlaşma Kriterleri Çerçevesinde Bütçe Disiplini ve Türkiye ile İlgili Bir Karşılaştırma", Sosyo-Ekonomi Dergisi, Temmuz-Aralık 2006.

- Ball L. and Mankıw G., "What Do Budget Deficit Do?, National Bureau of Economic Research", (NBER Working Paper Series), Cambridge 1995.

- Bankacılık Düzenleme ve Denetleme Kurumu Çalışma Tebliği, Krizden İstikrara $\begin{array}{lllll}\text { Türkiye } \quad \text { Tecrübesi, } & 3 . & \text { Bask1 } 3 & \text { Eylül } & 2010 .\end{array}$ (Erişim:http://www.bddk.org.tr/websitesi/turkce/raporlar/calisma_raporlari/7378krizde n $\% 20 \%$ C4\%B0stikrara\%20t\%C3\%BCrkiye $\% 20$ tecr\%C3\%BCbesi.pdf)

- Buchanan J. and Tollison R., The Theory of Public Choice, The University of Michigan Press America:1984.

- Cansız H., “Türkiye'de Devlet Bütçelerinin Değișen Hedefi: Faiz Dıșı Fazla Kavramı", Afyon Kocatepe Üniversitesi İIBF Dergisi, Cilt:8, Sayı:1, Afyon 2006.

- Delice G., "Finansal Krizler: Teorik Ve Tarihsel Bir Perspektif", Erciyes Üniversitesi İktisadi ve İdari Bilimler Fakültesi Dergisi, Sayı: 20, Ocak-Haziran 2003.

- Demir M., Çevik S., ve Beşer K., "Kamu Kesimi Finansman Açıklarının Ekonomik Etkileri: Türkiye Üzerine Bir İnceleme”, Marmara Üniversitesi İİBF Dergisi, Cilt XX, Say1:1, Y11: 2005.

- Devlet Planlama Teşkilatı (DPT), "Ekonomik Önlemler Uygulama Paketi”, Ankara 1994.

- Egeli H., "Mali Açıkların Ölçümüne Yönelik Bazı Gözlemler ve Bu Konuda Geliştirilmiş Alternatif Açık Ölçüleri”, Dokuz Eylül Üniversitesi Sosyal Bilimler Enstitüsü Dergisi Cilt 4, Say1:2, 2002.

- Eliana C., Albert F., "External Debt, Budget Deficits, and Inflation", (Editör: Jeffrey D. S., Developing Country Debt and Economic Performance), University of Chicago Press,January 1990.

- Erçel G., 2000 Y1lı Enflasyonu Düşürme Programı: Kur ve Para Politikası Uygulaması(Erişim:http://www.tcmb.gov.tr/yeni/evds/yayin/paraprog2/baskanmat5y.h tml).

- Erol Ü., “Kamu Açıkları İle Enflasyon Arasındaki Nedensellik İlişkisi”, Türkiye'de Kamu Ekonomisi ve Mali Kriz, XII. Maliye Sempozyumu, Antalyau Mayıs 1997. 
- Feltenstein A. and Iwata S., Why is It So Hard to Finance Budget Deficits? Problems of a Developing Country, International Monetary Fund, IMF Working Paper IMF Institute, May 2002.

- Fischer S., William E., The Economics of The Goverment Budget Constraint, The World Bank Research Observer, Vol:5, No:2. 1990.

- Giray F., Savunma Harcamaları ve Ekonomik Büyüme, Cumhuriyet Üniversitesi

- IİBF Dergisi, Cilt:5 Say1:1,2004.

- Karakurt B. ve Akdemir T., "Kurallı Maliye Politikası: Türkiye'de Kurallı Maliye Politikası Örnekleri”, Maliye Dergisi, Sayı 158, Ocak-Haziran 2010.

- Karluk R., Cumhuriyetin İlanından Günümüze Türkiye Ekonomisi'nde Yapısal Dönüşüm, Beta Yayınları, İstanbul 2007.

- Kesik A., "Bütçe Yönetimi İle Borç Yönetiminin Ayrılmasının Konsolide Bütçeye Yansimaları", 18.Maliye Sempozyumu, Girne-KKTC 2003.

- Kharas H. and Mishra D., "Looking Beyond The Budget Deficit", Editör: Shah, Anwar :Ensuring Accountability When There Is No Bottom Line, Vol. 1 of Handbook on Public Sector Performance Reviews. Washington D.C.: The World Bank 2003.

- Kumcu E., Krizler, Para ve İktisatçılar, Remzi Kitabevi, 2. Basım, İstanbul 2009.

- Öçal T., Türkiye Ekonomisi, Savaş Yayınevi, 2. Baskı Ankara 2005.

- Öniş Z., Beyond The 2001 Financial Crisis: The Political Economy of The New Phase of Neo-Liberal Restructuring in Turkey, Review of International Political Economy, Vol. 16, No.3, 2009.

- Pehlivan O., Kamu Maliyesi, Derya Kitabevi, Trabzon 2006.

- Pınar A., Maliye Politikası, Naturel Yayınları 3.Baskı, Ankara 2010.

- Sağbaş İ., "Kamu Maliyesinin Dönüşümü: Krizlerden Pozitif Ayrışmaya Reformlar ve Politikalar", (Ed: İ. Öztürk), Küresel Kriz ve Türkiye Ekonomisinin Dönüşümü, İstanbul Ticaret Odas1 Yayınları, Yayın No:2012-25, İstanbul 2012.

- Sak G., Konsolide Bütçe Açıkları ve Kamu Açıklarının Finansal Piyasalardaki Ağırlığının Faiz Oranları ve Döviz Kurları Üzerindeki Etkileri: Sıcak Para Politikası mı İzleniyor? İktisat, İşletme ve Finans Dergisi, Sayı:110 Mayıs 1995.

- Sonat A., "Kamu Kesimi Finansman Açıkları ve Dış Denge”, X. Türkiye Maliye Sempozyumu, Antalya Mayıs 1994.

- Şahin H., Türkiye Ekonomisi (Tarihsel Gelişimi- Bugünkü Durumu), Ezgi Kitabevi, 9.Bask1, Bursa 2007.

- Şen H., Sağbaș İ., Keskin A.; Bütçe Açıkları ve Açık Finansman Politikası-Teori ve Türkiye Uygulamas1-, Orion Yayınları, Ankara 2007.

- Şener O., Teori ve Uygulamada Kamu Ekonomisi, Beta Yayınları 10.Baskı, İstanbul 2008.

- Şimşek H. A., “Türkiye'de 2000 Sonrasında Uygulanan İstikrar Programlarının Kamu Maliyesine Etkileri”, Finans Politik \& Ekonomik Yorumlar Dergisi Cilt: 44 Sayı:512, 2007.

- Tanzı V., blejer M. and Teijeiro M., Inflation and the Measurement of Fiscal Deficits, International Monetary Fund, Fiscal Affairs Department IMF Workıng Paper March 13, 1987.

- Tunalı H., "2000 Sonrası Türkiye Ekonomisinin Yol Haritasının Belirlenmesinde IMF'nin Etkisi”,(Ed: Y. ALPAYDIN, H. TUNALI), 2000 Sonrası Türkiye İktisadının Değişimi, İstanbul Ticaret Odası Yayınları Yayın No:2011-31, İstanbul 2011.

- Tüğen K., Devlet Bütçesi, Bassaray Matbaası, İzmir 2009.

- Ulusoy A., Devlet Borçlanması, Mikro Yayıncılık, Trabzon 2006. 
- Y Yldırım k. ve Özcan S. E.; "Bütçe Açıklarının Sürdürülebilirliği-1970-2005- Türkiye Örneği”, Dumlupınar Üniversitesi Sosyal Bilimler Dergisi Sayı:30, Kütahya 2011.

- European Community Statistical Office ;Eurostat (Avrupa Birliği, Avrupa İstatistik Ofisi): ec.europa.eu/eurostat.

- Orta Vadeli Program (OVP) (2010-2012), Bakanlar Kurulu Kararı, Karar Sayıs1: 2009/15430, Resmi Gazete Yayınlanma Tarihi: 16 Eylül 2009, Resmi Gazete No: 27351 (Mükerrer).

- Orta Vadeli Program, 2012-2015, Bakanlar Kurulu Karar1, Karar Sayıs1: 2012/3793, Resmi Gazete Yayınlanma Tarihi: 9 Ekim 2012, Resmi Gazete No: 28436 (Mükerrer).

- TCMB, “Güçlü Ekonomiye Geçiş Programı", 2001, (Erişim:www.tcmb.gov.tr). 